\title{
Modeling thermal convection in supradetachment basins: example from western Norway
}

\author{
A. SOUCHE*, M. DABROWSKI AND T. B. ANDERSEN \\ Physics of Geological Processes (PGP), University of Oslo, Oslo, Norway
}

\begin{abstract}
The juxtaposition of fault-bounded sedimentary basins, above crustal-scale detachments, with warmer exhumed footwalls can lead to thermal convection of the fluids in the sediments. The Devonian basins of western Norway are examples of supradetachment basins that formed in the hanging wall of the Nordfjord-Sogn Detachment Zone. In the central part of the Hornelen and Kvamshesten basins, the basin-fill is chiefly represented by fluvial sandstones and minor lacustrine siltstones, whereas the fault margins are dominated by fanglomerates along the detachment contact. Prominent alteration and low-greenschist facies metamorphic conditions are associated with the peak temperature estimates of the sediments close to the detachment shear zone. Fluid circulation may have been active during the burial of the sediments, and we quantify the potential role played by thermal convection in redistributing heat within the basins. Different models are tested with homogeneous and layered basin-fill and with material transport properties corresponding to sandstones and siltstones. We found that thermally driven fluid flow is expected in supradetachment basins as a transient process during the exhumation of warmer footwalls. We demonstrate that the fluid flow may have significantly affected the temperature distribution in the upper five kilometers of the Devonian basins of western Norway. The temperature anomaly induced by the flow may locally reach about $80^{\circ} \mathrm{C}$. The sedimentary layering formed by sand- and siltstones strata does not inhibit fluid circulation at the scale of the basin. The presence of fluid pathways along the detachment has an important impact on the flow and allows an efficient drainage of the basin by channelizing fluids upward along the detachment.
\end{abstract}

Key words: Devonian basins Norway, groundwater flow, Nordford-Sogn Detachment Zone, sedimentary layers, shear zone, temperature anomaly, thermal convection

Received 21 April 2013; accepted 28 April 2013

Corresponding author: Alban Souche, Physics of Geological Processes (PGP), University of Oslo, P.O. Box 1048, Blindern, 0316 Oslo, Norway.

Email: alban.souche@ife.no. Tel: +47 638066 54. Fax: +47 63816356.

*Present address: Institute for Energy Technology (IFE), Environmental Technology, P.O. Box 40, 2027, Kjeller, Norway

Geofluids (2013)

\section{INTRODUCTION}

Fluid flow in sedimentary basins can play a major role in redistributing mass and heat in the system (Wood \& Hewett 1982; Person et al. 1996). It can be driven by several factors such as the surface topography, the compaction of the sediments, or buoyancy instabilities of the fluid(s). Topography-driven flow may control the circulation of meteoritic water through aquifers when recharge areas are located at higher elevation than discharge areas. This type of flow can result, for example, in the occurrence of thermal springs in mountainous areas (Andrews et al. 1982; Levet et al. 2002; Brumm et al. 2009). Compaction-driven flow operates with a limited amount of fluids initially trapped within the sediments. During burial, the expelled fluids may transport solutes and cause precipitation of minerals within various units of the sedimentary basin (Bjørlykke \& Høeg 1997; Bjørlykke 1999). Buoyancy-driven flow is induced by variations of the fluid density within porous media. The density increase resulting from dissolution of $\mathrm{CO}_{2}$ into brine may lead to convective flow and storage of $\mathrm{CO}_{2}$-rich brine in deep part of saline aquifers (Hidalgo \& Carrera 2009; Pau et al. 2010).

This study focuses on buoyancy-driven flow induced by the thermal expansion of a fluid (water) when heated. This process, referred as thermal convection or free convection in sedimentary basins, is driven by basal heating and lateral thermal gradient. Analog experiments of Rayleigh-Bénard 
thermal convection in fully saturated porous media document the onset of instability in terms of the critical Rayleigh number (Elder 1967; Combarnous \& Bia 1971; Palm et al. 1972). Depending on the boundary conditions, the value of the critical Rayleigh number can vary from 27 in the case of a permeable surface to 39 in the case of an impermeable surface (McKibbin \& O'Sullivan 1981). Thus, in a horizontally stratified basin where a permeable sandstone aquifer is embedded in impermeable shale, the critical Rayleigh number of the system is 39 , which corresponds roughly to a minimum aquifer thickness of $330 \mathrm{~m}$ with permeability of 1 Darcy under a geothermal gradient of $30^{\circ} \mathrm{C} \mathrm{km}^{-1}$ (Bjørlykke et al. 1988). As suggested by Bjørlykke et al. (1988), such thick permeable units might be rare in most sedimentary basins. However, this point of view is partially biased by the binary mode of heat transfer suggested by the Rayleigh-Bénard experiment (i.e., either conduction below the critical Rayleigh number or conduction with convection above the critical Rayleigh number). In a geological setting where the layers and the isotherms may be tilted or slanted (Fig. 1), it is misleading to apply the predictions obtained with a Rayleigh-Bénard setup where the boundary temperature conditions remain perfectly horizontal. The horizontal component of the temperature gradient leads unconditionally to fluid motion in permeable rocks, even below critical Rayleigh number (Combarnous \& Bia 1971; Bories \& Combarnous 1973; Bjørlykke et al. 1988; Gouze et al. 1994; Wangen 1994, 1997; Simms \& Garven 2004). This type of fluid motion is called non-Rayleigh convection, as opposed to Rayleigh convection above critical Rayleigh number (Fig. 1).

In the case of a crustal-scale detachment and supradetachment basins addressed in this article, sedimentary basins may be in contact with potentially high permeable strata and conduits along fault margins. Transient thermal effects like heating of the basin from the progressive exhumation of a 'hot' footwall and shear heating in the detachment shear zone may have large effects on the fluid flow potential in sedimentary basins (Souche et al. 2012b). High peak temperature conditions were estimated close to the detachment fault in the supradetachment basins of western Norway (Svensen et al. 2001; Souche et al. 2012a). The high temperature conditions could have resulted from the conductive heating of the basin adjacent to the warmer exhumed footwall. The conditions could also arise from the circulation of hot fluids in the basin and along the detachment zone. We consider the specific geological setting of the post-Caledonian detachment zone in western Norway, which is geologically constrained both from the thermobarometric and geochronological studies of the footwall (e.g., Labrousse et al. 2004; Hacker et al. 2010) and from the architecture of the supradetachment basins in the hanging wall (e.g., Osmundsen \& Andersen 2001). We investigate whether the slanted isotherms, produced by the exhumation of the footwall during the extension, could lead to significant fluid flow in the supradetachment basins. Finally, we quantify the temperature anomaly induced by the fluid circulation in the sediments and evaluate its

(A) Rayleigh-Bénard experiments in porous media:

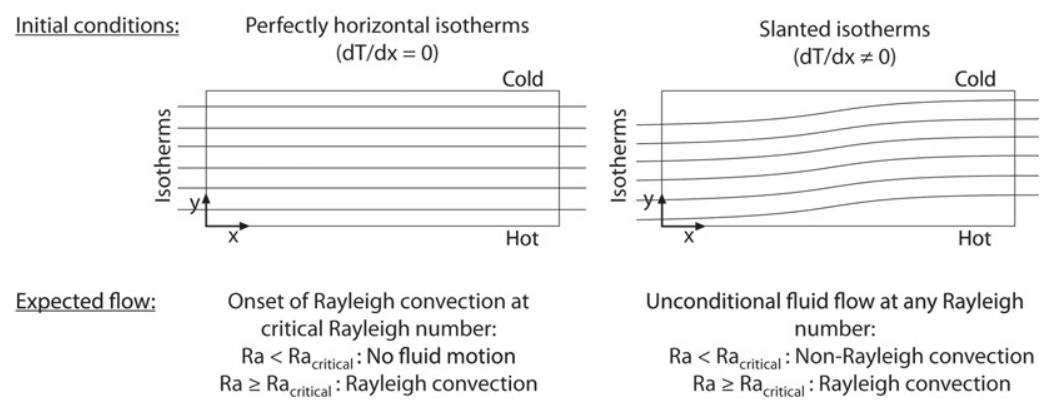

(B) Crustal detachment setting:

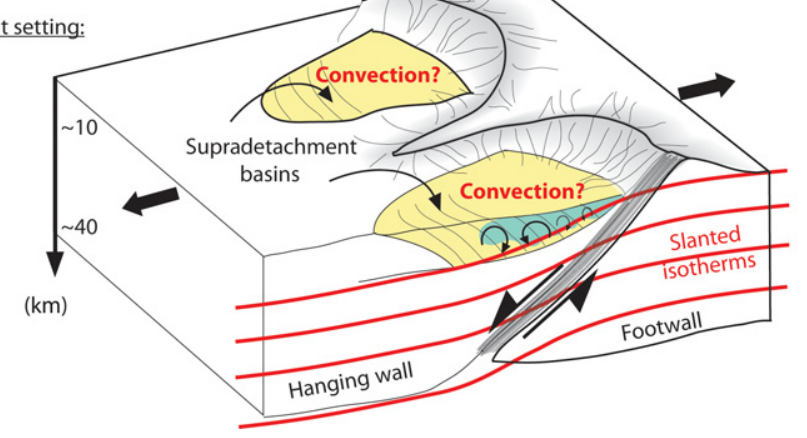

Fig. 1. (A) Rayleigh-Bénard experiments in porous media and expected type of fluid convection. In the case of perfectly horizontal isotherms, fluid flow only occurs after the onset of convection above the critical Rayleigh number. In the case of slanted isotherms, fluid flow will always occur due to the horizontal component of the thermal gradient. The fluid motion below the critical Rayleigh number is known as non-Rayleigh convection. (B) Sketch of a crustal detachment with supradetachment basins at the surface. The exhumation of the footwall and the burial of the hanging wall may, respectively, lead to the rise and depression of the isotherms in the area. The resulting slanted isotherms may control the fluid flow in the supradetachment basins. 
impact on the peak temperature conditions of the sedimentary basins.

These questions are of particular interest in understanding the thermal evolution of the Devonian basins of western Norway but also, with a broader perspective, relevant particularly for the thermal evolution of half-graben basins that have a characteristic tilt of the sedimentary layers.

\section{GEOLOGICAL SETTING}

\section{The Nordfjord-Sogn Detachment Zone}

The Nordfjord-Sogn Detachment Zone (NSDZ) is a crustal-scale extensional detachment that formed during gravitational collapse and dismantlement of the Caledonian orogeny in the Early to Late Devonian (Norton 1986; Seranne \& Seguret 1987; Seguret et al. 1989; Andersen \& Jamtveit 1990; Andersen 1998; Osmundsen et al. 1998). The NSDZ juxtaposes lower Devonian (approximately 415-400 Ma) high- to ultra-high-pressure rocks in its footwall (Hacker et al. 2010) with sedimentary rocks of nearly the same age in its hanging wall (Fig. 2A). The regional extension was accommodated by strike-slip and listric-normal faulting at the surface, which controlled the sedimentary architecture of the supradetachment basins (Osmundsen et al. 2000).

The exhumation of the footwall of the NSDZ is documented by a number of tectonic and petrological studies of the eclogite-facies Western Gneiss Region (WGR; Hacker et al. 2003; Labrousse et al. 2004; Root et al. 2005; Johnston et al. 2007; Kylander-Clark et al. 2009; Young et al. 2011). The pressure-temperature-time evolution of the footwall indicates that the decompression, corresponding in some area to exhumation $>100 \mathrm{~km}$, occurred in a time window of 5-10 Myr (Andersen \& Jamtveit 1990; Hacker et al. 2003; Young et al. 2011). The Caledonian nappes of the Hyllestad complex below the Solund basin (Fig. 2A), and the Lykkebø/Eikefjord groups below the Hornelen basin, recorded high-pressure metamorphism in the range of 10-15 kbar (approximately $60 \mathrm{~km}$ burial) with peak temperatures of $550-600^{\circ} \mathrm{C}$ (Hacker et al. 2003; Johnston et al. 2007). These units are separated from the basins by a mylonitic shear zone with an average shear strain of $\gamma \geq 20$ (Andersen \& Jamtveit 1990; Hacker et al. 2003; Marques et al. 2007). A simple reconstruction of a normal-sense shear zone with a dip of $30^{\circ}$ and a thickness of $5 \mathrm{~km}$ results in the vertical displacement of $50 \mathrm{~km}$, which is compatible with the geological observations and the exhumation of the HP Caledonian nappes.

\section{Formation of the Devonian supradetachment basins}

The most prominent geological feature of the Devonian basins is their tectonically controlled architecture (Bryhni
1964; Steel et al. 1977; Folkestad \& Steel 2001). The basins developed in a continental setting characterized by debris flows, high-energy fluvial processes, and high sedimentation rate $(>2.5 \mathrm{~mm}$ per year; Nilsen \& McLaughlin 1985). Their architecture and geometry was controlled by the motion above extensional listric-normal faults beneath the basins (Osmundsen \& Andersen 2001). Along the fault margins, the basins are filled with fanglomerates formed by proximal debris flows and alluvial fans (Fig. 2E), and they are filled with distal fluvial and lacustrine deposits in their central parts. In the central part of the Hornelen basin (Figs 2A), the bedding exhibits a relatively constant eastward tilt of approximately $30^{\circ}$ dipping toward the detachment fault. Each depositional unit is typically close to $100 \mathrm{~m}$ thick and comprises rhythmic deposition of cyclothems (Fig. 2B). These cyclothems consist of prograding coarsening-up-fining sequences with sedimentary facies varying from finer sand- and siltstones to conglomerates (Figs 3 ). Within the Hornelen basin, this pattern repeats itself more than 100 times resulting in about $25 \mathrm{~km}$ of preserved stratigraphic thickness (Steel et al. 1977). However, the burial depth has not exceeded 10-14 km (Svensen et al. 2001), and the stratigraphic thickness accumulated by lateral growth during episodic eastward shifts of the depocenter in response to tectonic motions (Fig. 2E). Similar tectonic control on deep basins have been described from the Ridge basin in California (13.5 km of dominantly continental formation), which has been proposed as a more recent example to the sedimentation along the north margin of the Hornelen basin (Nilsen \& McLaughlin 1985).

Contemporaneous with the main E-W extension, N-S shortening affected western Norway giving rise to overall transtension (Krabbendam \& Dewey 1998; Osmundsen \& Andersen 2001). The N-S shortening resulted in largescale folding of the sedimentary strata around E-W fold axis, and in the characteristic present-day saucer-shape geometry of the basins and detachment mylonites (Fig. 2A,D).

The peak temperature conditions of the basins have been documented from authigenic minerals and fluid-inclusion studies by Svensen et al. (2001) and by Raman spectroscopy on organic carbon by Souche et al. (2012a). The highest temperatures within the basins are found close to the detachment fault. Locally, the sediments were exposed to temperatures of $345^{\circ} \mathrm{C}$, corresponding to a geothermal gradient as high as $37^{\circ} \mathrm{C} \mathrm{km}^{-1}$ during the exhumation of the metamorphic basement.

\section{The basin-detachment contact}

The contact between the Devonian sediments and the shear zone of the extensional detachment typically occurs along a sharp geological boundary (Fig. 4). The brittle 
(A)
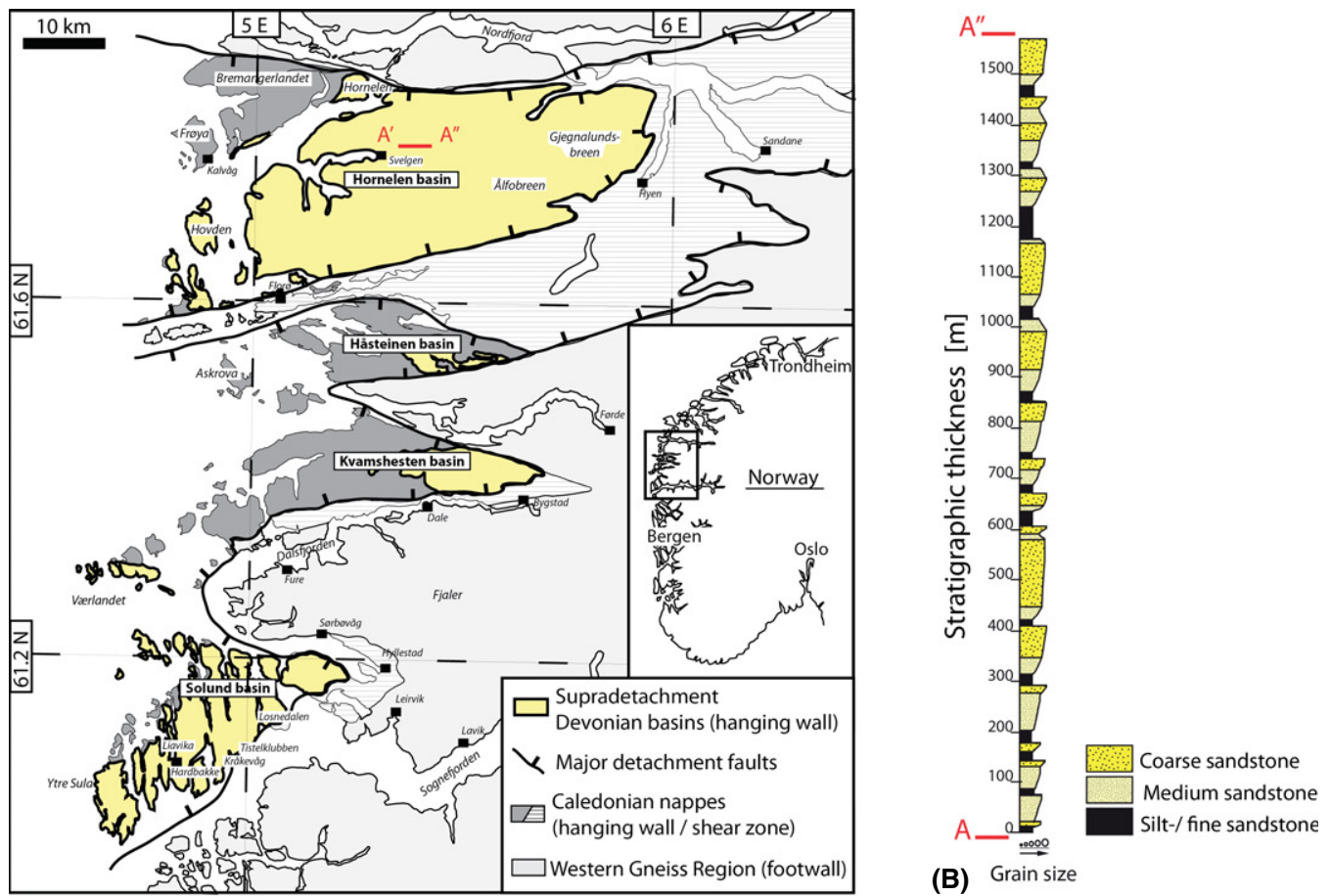

(C) 430-400 Ma: Caledonian orogeny

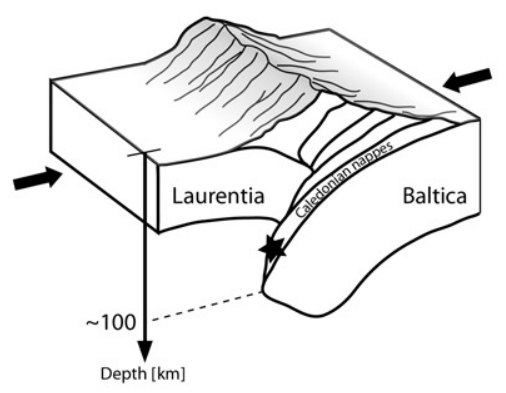

(D) 400-385 Ma: Post-orogenic extension

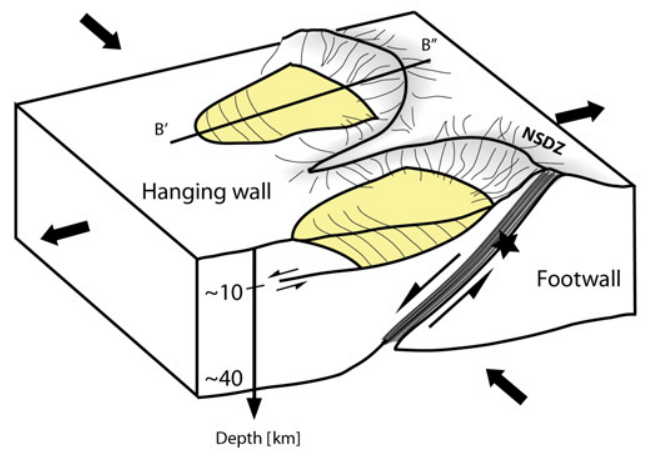

(E)

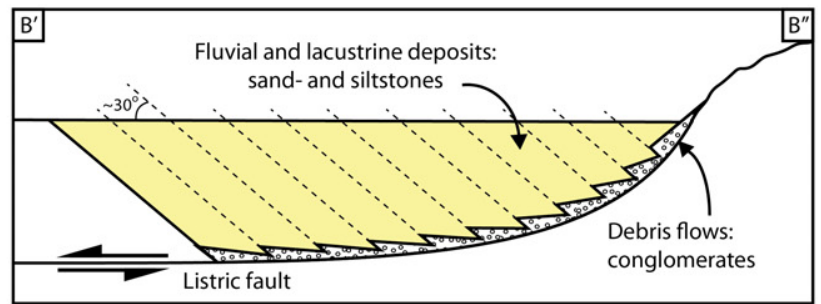

Fig. 2. (A) Simplified geological map showing the location of the supradetachment basins and the crustal-scale Nordfjord-Sogn Detachment Zone (NSDZ) in western Norway. (B) Stratigraphic log along the path $A^{\prime}-A^{\prime \prime}$ in the central part of the Hornelen basin modified from Steel et al. (1977). (C) Schematic reconstitution of the Caledonian collision between Laurentia and Baltica. The black star illustrates the HP burial conditions of the Caledonian nappes exposed today in the shear zone of the NSDZ. (D) Schematic illustration of the formation of the Devonian basins above the NSDZ. (E) A simplified cross-section across the Devonian basins.

contact between the sediments and the mylonitic shear zone is represented by a $1-2 \mathrm{~m}$ thick gauge zone, filled with calcite and late open fractures. Multiple generations of cataclasite and pseudotachylyte are observed along the Solund fault (Fig. 4B), on outcrop, and thin-section scales, suggesting recurrent brittle movements along the fault 
Fig. 3. Examples of sediments found in the Devonian basins of western Norway. (A) Coarse conglomerates in the Solund basin. (B) Red sandstones and conglomerates in the Solund basin, near Liavika.
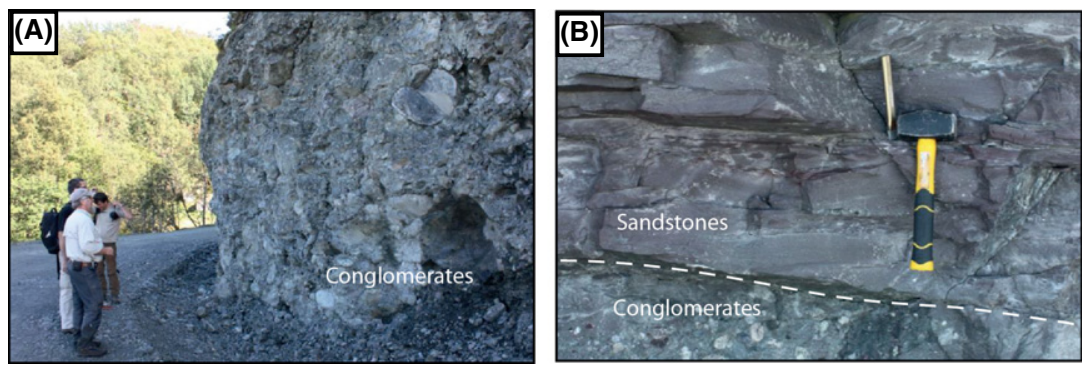
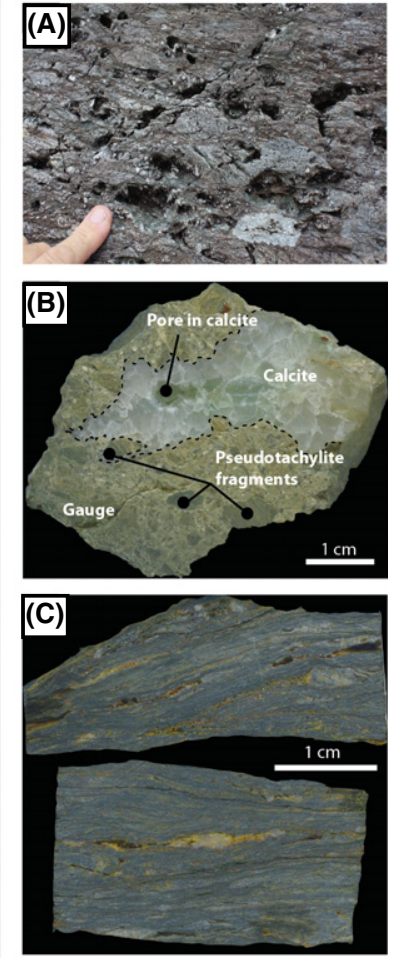

Fig. 4. Fault zone (B) between the Solund basin (A) and the mylonitic shear zone of the detachment (C), picture taken near Tistelklubben. (A) Sheared conglomerates few meters above the detachment contact, near Tistelklubben. (B) Gauge from the cataclastic zone, near Losnedalen. (C) Mylonitic texture of the shear zone, few meters beneath the detachment contact, near Tistelklubben.

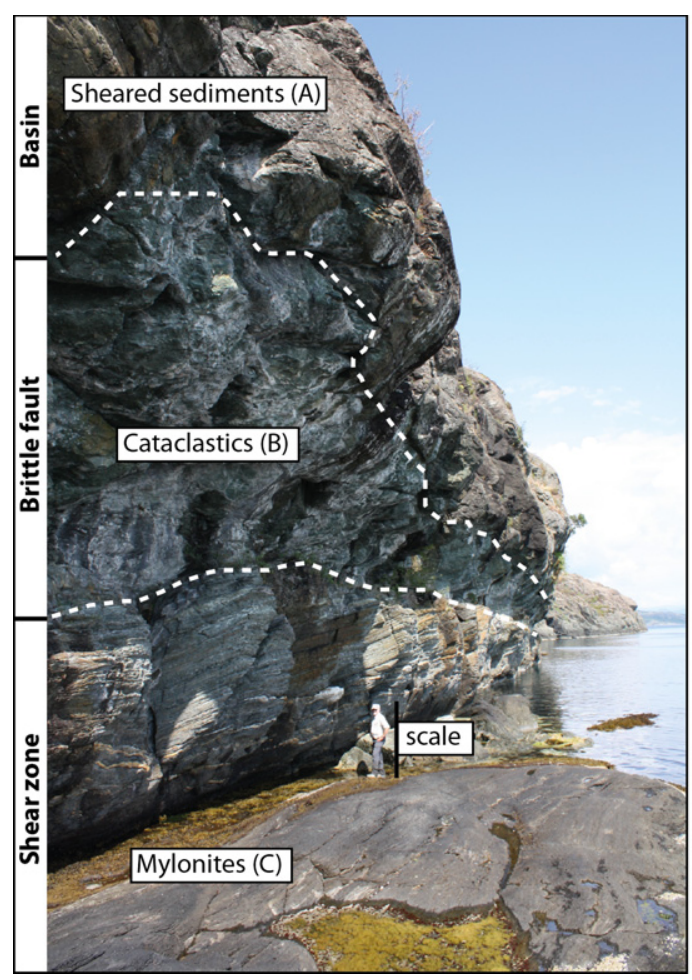

plane, similar to those described along the Kvamshesten basin (Braathen et al. 2004). Several segments of the basin-bounding faults have experienced minor brittle postdepositional reactivation as documented by Torsvik et al. (1992).

Few meters below the contact, the rock belongs to the shear zone of the detachment and exhibits extreme mylonitic fabrics (Fig. 4C). The foliation shows a striking alignment with the main fault. The schistosity and friability of the mylonites can potentially allow fluid circulation within the upper part of the shear zone.

Few meters above the contact, sheared conglomerates mark the structural base of the Solund basin (Fig. 4A). In some places, the deformation overprints the sedimentary structure and brings uncertainties regarding the protolith of the fault rocks (Fig. 4A). These highly sheared and fractured rocks commonly have a large number of quartz fragments that could be either detrital or derived from fragmented veins.

\section{Evidence for fluid activity}

The sedimentary rocks in the Devonian basins of western Norway show a series of diagenetic and metamorphic alterations that reflect the activation of fluid processes during the burial of the sediments (Seranne \& Seguret 1987; Odling \& Larsen 2000; Svensen et al. 2001; Beinlich et al. 2010). The maximum burial was marked by the formation of locally dense network of metamorphic veins (Svensen et al. 2001). The veins host authigenic mineral such as epidote, chlorite, biotite, and local actinolite that give constrains on the peak temperature conditions of the sediments. The density of veins increases toward the detachment contact. Two examples of such network are presented in Fig. 5B,C.

The common presence of carbonate in outcrop-scale veins and in former pore-space on the thin-section scale documents a fluid activity in the sediments. The precipitation of carbonate resulted in the clogging of the primary 

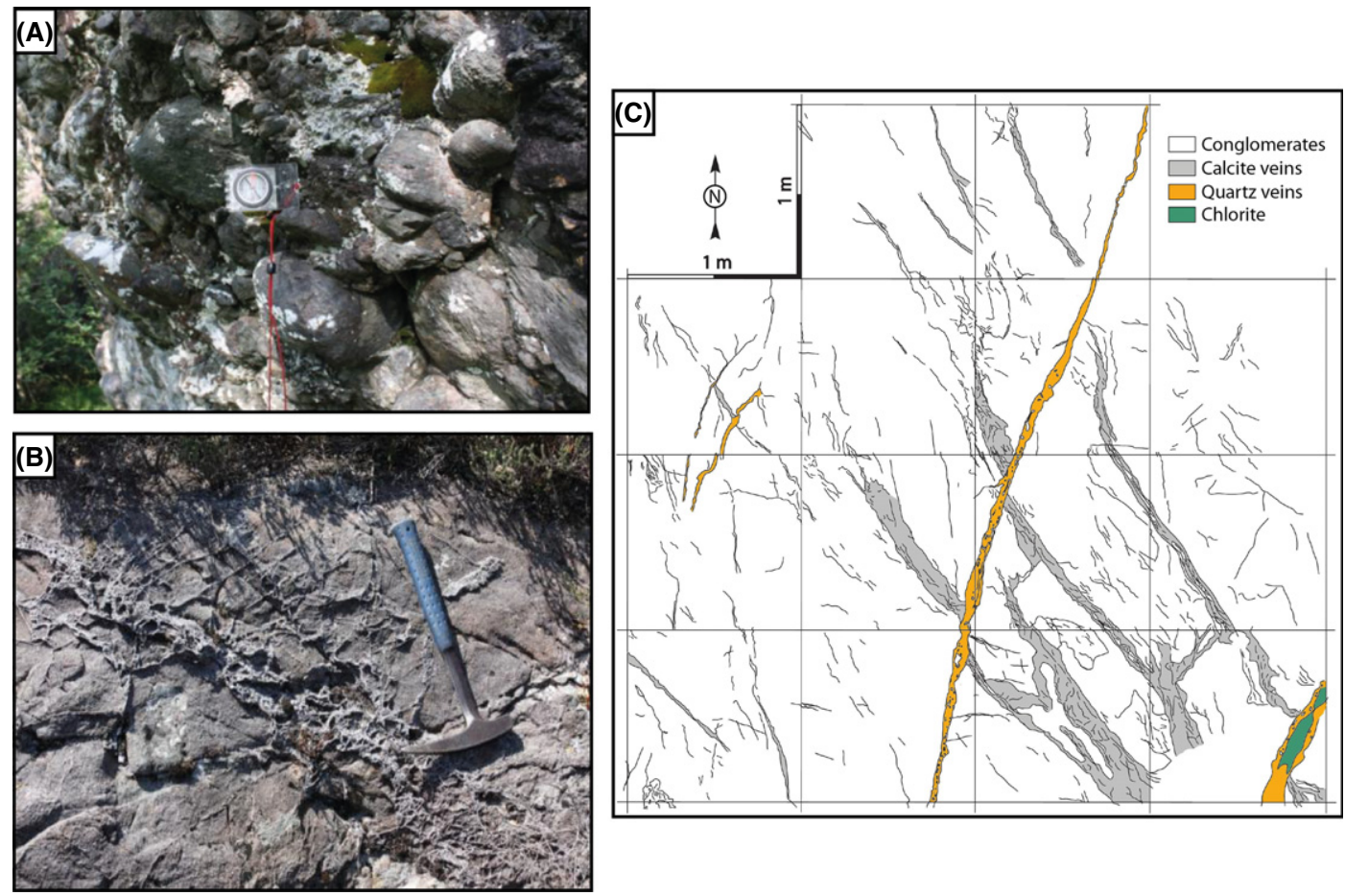

Fig. 5. (A) Solund conglomerates containing abundant altered ultramafic pebbles and boulders. The matrix is also altered and friable on the outcrop, letting the pebbles stick out. $(B, C)$ Vein patterns at different scales, cutting clasts and matrix in the Solund conglomerates close the detachment contact (near Kråkevåg).

porosity that does not permit in situ measurements of the porosity or the permeability of the sediments.

Alteration including carbonatization of ultramafic clasts in the Solund basin occurred in situ during the burial of the sediments (Beinlich et al. 2010). In conglomeratic lithologies where ultramafic clasts may constitute up to $20 \%$ of the sediments, the surrounding matrix is also altered (Fig. 5A). The widespread alteration of the ultramafic clasts together with the matrix of the conglomerates demonstrates a pervasive interaction between the clastic material and a pore fluid circulation in the basin (Beinlich et al. 2010). A similar conclusion regarding pervasive fluid flow in the basins has been suggested to account for the oxidation of detrital carbonaceous material associated with the recurrent presence of hematite in the matrix of the sediments (Souche et al. 2012a).

\section{MODEL SETUP}

\section{Lithospheric- and basin-scale configurations}

The background temperature, which is a necessary parameter in our basin-scale fluid flow model, is obtained by modeling the thermal evolution of a crustal-scale detachment in a lithospheric-scale model of the NSDZ (Fig. 6A,B), referred to as lithospheric model. We incorporate geological constrains available from the literature regarding the geometry and the thermochronology of rock units in western Norway (Souche et al. 2012b). The duration of the deformation responsible for the exhumation of footwall high-pressure units ('HP unit' in Fig. 6A,B) from a depth of $60-20 \mathrm{~km}$ is set to $5 \mathrm{Myr}$. At the same time, the hanging wall subsides along the detachment creating accommodation space for the sediments ('basin unit' in Fig. 6B). As the lithospheric model attains the final configuration as shown in Fig. 6B, we assume that the basin is fully developed with compacted sediments of a thickness up to $10 \mathrm{~km}$.

Fluid flow simulations are then performed within the basin model, which is nested in the lithospheric model. In configuration I (Fig. 6C), the basin is filled with homogenous sediments. In the configuration II, the basin is filled with discrete layers that can have different transport properties (Fig. 6D). The layers are tilted toward the detachment fault with a constant dip of $30^{\circ}$ similar to the field analog. The marginal fanglomerates in the basin and the cataclastic fault zone along the detachment contact are taken into account in the model by introducing an additional permeable layer along the detachment fault (Fig. 6D). This layer is referred to as the 'fault-cored pathway' in the remaining parts of the article. It connects all the internal layers of the basin from their base to the surface. The fault-cored pathway can be seen as a preferred pathway for the fluid where permeability is higher than the rest of the basin. 
Fig. 6. (A) Initial and (B) final configurations of the lithospheric model used to provide the background temperature field for the fluid flow simulations in the basin. Setup representative for the evolution of the Nordfjord-Sogn Detachment Zone (NSDZ) with exhumation of high-pressure rocks (HP unit) from 60 to $20 \mathrm{~km}$ depth in 5 Myr. (a) upper crust; (b) predefined crustal-scale shear zone geometry; (c) lower crust; (d) mantle lithosphere. (C) Uniform basin-fill configuration and (D) layered basin-fill configuration used for fluid flow simulations. (1) Stack of discrete layers dipping $30^{\circ}$ toward the detachment similar to the field analog; (2) 'fault-cored pathway' emulating the marginal coarse deposits and the cataclastic fault zone along the contact with the detachment shear zone. Note that the thicknesses of the layers in (D) are not to scale.
Listhospheric model:

background temperature modelling

(A)

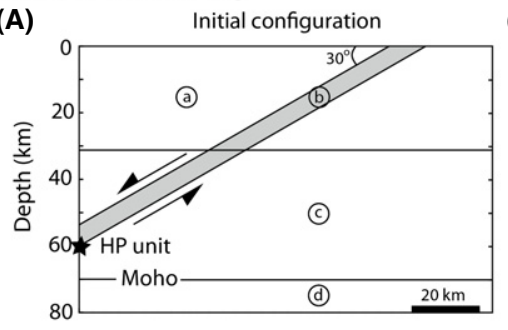

(B) Final configuration (+5 My)

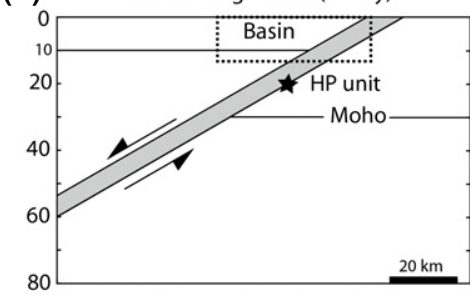

Basin model (zoom into the basin): fluid flow modelling

(C) Configuration I:

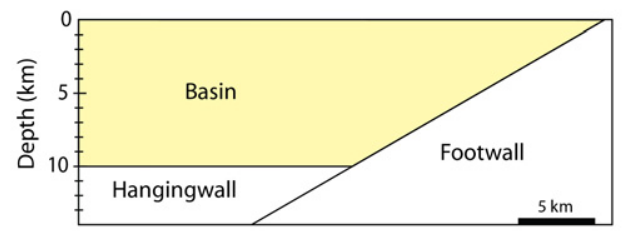

(D) Configuration II:

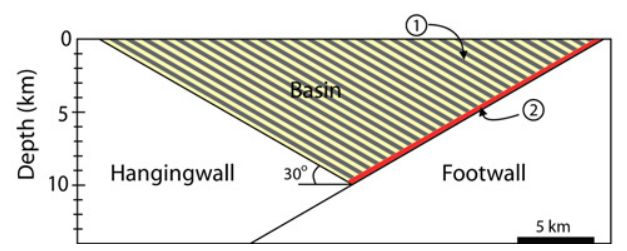

The basin configuration is not meant to reproduce 'iconically' the architecture of the Devonian basins of western Norway, but to capture prominent geological features that are essential in terms of the fluid flow potential. Note also that the basin model has the same horizontal and lateral extent $(120 \times 80 \mathrm{~km})$ and the same configuration of the lithospheric units as the lithospheric model at the final configuration (Fig. 6B).

\section{Thermal and transport properties}

The thermal conductivity is given as function of temperature in both the lithospheric and basin models. The specific parameters $a$ and $b$ (Table 1) are taken for felsic rocks for the upper crust, mafic rocks for the lower crust, and ultramafic rocks for the mantle lithosphere (Clauser \& Huenges 1995). Radioactive heat is considered in the lithospheric model assuming a constant heat production within each layer (Table 1). Note that this heat source is neglected when computing fluid flow in the basin model. The fluid

(water) properties such as the density (Fig. 7), viscosity, and specific heat capacity are functions of the temperature and pressure and are interpolated from a precalculated table derived from the PROST library (Bauer 1998).

The rock transport properties such as the porosity and permeability (Fig. 8) are estimated using characteristic trends for siltstones and sandstones as no measured data are available from the basins. The porosity follows an exponential decay with depth as expressed by Athy's law (Athy 1930)

$\phi=\phi_{0} \mathrm{e}^{-\alpha z}$

The depth $z$ is measure from the surface. The surface porosity $\phi_{0}$ and the decay constant $\alpha$ depend on the sedimentary lithologies (Table 2). Different values of $\phi_{0}$ and $\alpha$ may be found in the literature and we use here the parameters provided by Hantschel \& Kauerauf (2009), which results in a lower estimate of the porosity at any depth compared with the porosity of sandstone units in the North Sea (Sclater \& Christie 1980).

Table 1 Density, thermal properties, and heat generation of the model units.

\begin{tabular}{|c|c|c|c|c|c|c|}
\hline & Symbol & Unit & Sediments & Upper crust & Lower crust & Mantle lithosphere \\
\hline Density & $\rho$ & $\mathrm{kg} \mathrm{m}^{-3}$ & 2400 & 2700 & 2900 & 3300 \\
\hline Specific heat capacity & $C_{p}$ & $\mathrm{~J} \mathrm{~kg}^{-1}$ per K & 1000 & 1000 & 1000 & 1000 \\
\hline Thermal conductivity rock* & $\kappa$ & $\mathrm{W} \mathrm{m}^{-1}$ per $\mathrm{K}$ & \multicolumn{2}{|c|}{$a=0.64 ; b=807$} & $a=1.18 ; b=474$ & $a=0.73 ; b=1293$ \\
\hline Radioactive heat production ${ }^{\dagger}$ & - & $\mathrm{W} \mathrm{m}^{-3}$ & $1.2 \times 10^{-6}$ & $1 \times 10^{-6}$ & $4 \times 10^{-7}$ & $2 \times 10^{-8}$ \\
\hline
\end{tabular}

${ }^{*} \mathrm{~K}=\mathrm{a}+\mathrm{b} /(T+350)$, where $T$ is the temperature expressed in ${ }^{\circ} \mathrm{C}$ [after Clauser \& Huenges (1995)]. ${ }^{\dagger}$ After Hasterok \& Chapman (2011). 


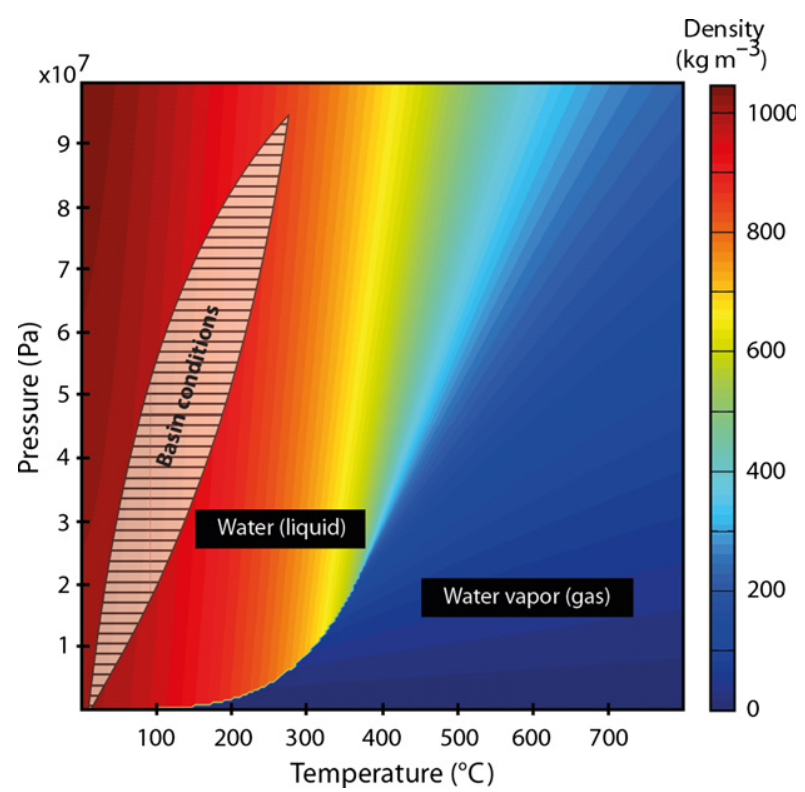

Fig. 7. Fluid density as a function of temperature and pressure. Basin conditions stay within the stability field of liquid phase (single phase flow) during the simulation. The dashed area corresponds to the initial conditions of the fluid in the basin.
(A) Porosity (\%)

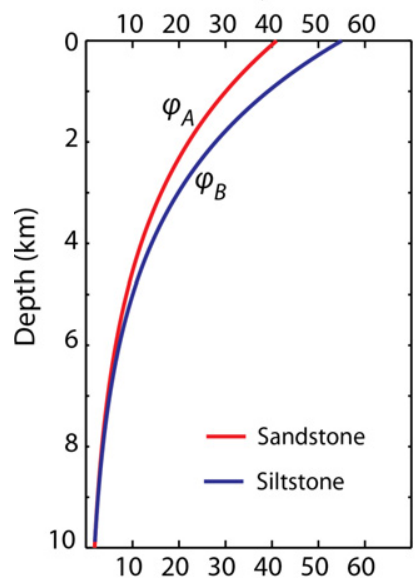

(B) Permability $(\mathrm{mD})$

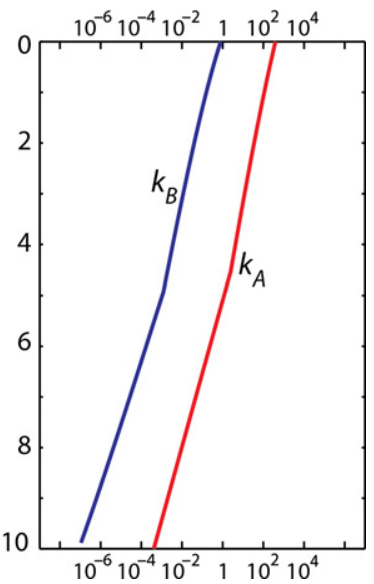

Fig. 8. (A) Porosity $\phi_{A}$ and $\phi_{B}$ and (B) permeability $\kappa_{A}$ and $\kappa_{B}$ versus depth for typical sand- and siltstones, respectively. The surface permeabilities are $\kappa_{A}(0)=395 \mathrm{mD}$ and $\kappa_{B}(0)=0.8 \mathrm{mD}$ and reduces at $5 \mathrm{~km}$ depth to $\kappa_{A}$ $(5 \mathrm{~km})=1.2 \mathrm{mD}$ and $\kappa_{\mathrm{A}}(5 \mathrm{~km})=10^{-3} \mathrm{mD}$.

Table 2 Parameters used in evaluating transport properties.

\begin{tabular}{llllr}
\hline & $\phi_{0}$ & $\alpha\left[\frac{1}{\mathrm{~km}}\right]$ & $S\left[\frac{1}{\mathrm{~m}}\right]$ & $\beta$ \\
\hline Sandstone & 0.41 & 0.31 & $10^{6}$ & 10.0 \\
Siltstone & 0.55 & 0.34 & $10^{7}$ & 0.5 \\
\hline
\end{tabular}

Works by Ingebritsen \& Manning (1999) and Manning \& Ingebritsen (1999) provide a good basis for permeability relationships within the crust, but their method is mostly applicable for depth $>5 \mathrm{~km}$ and is not suitable for basin-scale model where most of the flow is expected to occur at shallower depth. Here, we calculate the permeability $\kappa$ based on the porosity according to a revised KozenyCarman relationship (Ungerer et al. 1990):

$\kappa_{(\phi)}=2 \times 10^{14} \beta \frac{\phi^{\prime 3}}{S^{2}\left(1-\phi^{\prime}\right)^{2}} \quad$ if $\phi^{\prime} \geq 0.1$

$\kappa_{(\phi)}=2 \times 10^{16} \beta \frac{\phi^{\prime 5}}{S^{2}\left(1-\phi^{\prime}\right)^{2}} \quad$ if $\phi^{\prime}<0.1$

The parameters $S$ and $\beta$ are, respectively, the specific surface area and the scaling factor depending on the lithologies (Table 2 ). The corrected porosity $\phi^{\prime}$ is given by the difference between the porosity $\phi$ and the threshold porosity $\phi_{c}$, for which the pores connectivity is lost and the permeability vanishes. The corrected porosity can be expressed as a function of the specific surface area:

$\phi^{\prime}=\phi-\phi_{c}=\phi-3.1 \times 10^{-10} S$.

\section{Initial background temperature}

The initial temperature distribution is obtained by modeling thermal effects related to the exhumation of the lower crust along a crustal-scale normal shear zone using the lithospheric model (Fig. 9). In these preliminary simulations, thermal effects related to fluid flow in the basin are neglected. The rate of exhumation is an important parameter with regard to the temperature field evolution in the system. Fast-evolving detachments result in a large amount of heat at the base of supradetachment basins due to the exhumation of the relatively hot footwall and shear heating generated in the shear zone underlying the basin (Souche et al. 2012b). After exhumation of the footwall (5 Myr), the temperature field (Fig. 9B) exhibits the highest thermal gradient between the hanging wall and the footwall. This corresponds to the configuration where thermal convection is most likely to occur in the top basin unit. We therefore use this temperature field as an initial background temperature for the fluid flow simulations.

\section{Flow, temperature, and pressure conditions (basin model)}

The top boundary of the model is open to fluid flow, that is, the pore fluid is free to enter or leave the system. The temperature at the surface is either set to $10^{\circ} \mathrm{C}$ if the fluid enters the model or considered with zero flux boundary condition if the fluid leaves the model. The bottom boundary of the model, at $80 \mathrm{~km}$ depth, is set to $780^{\circ} \mathrm{C}$. Zero heat flux boundary conditions are used on both lateral walls. The pressure boundary condition is constrained only at the surface of the model and is set to atmospheric pressure of $10^{5} \mathrm{~Pa}$. 
(A)

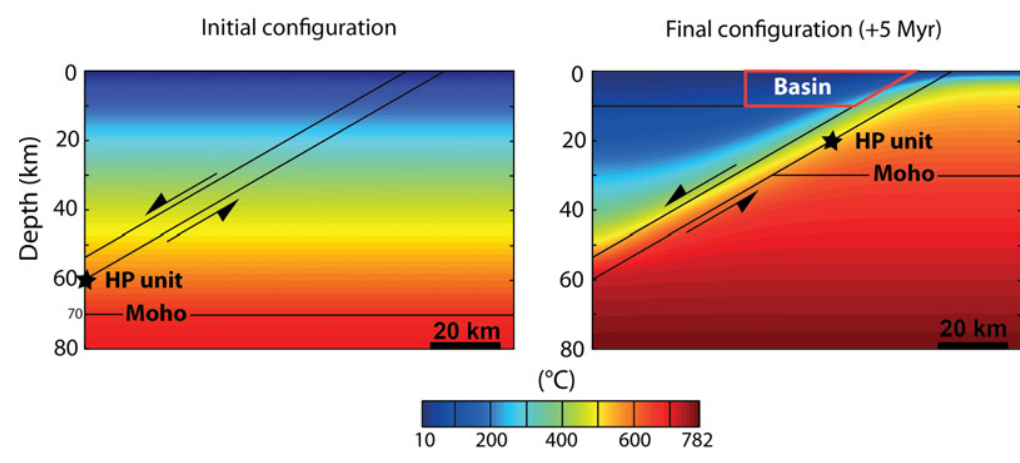

(C)

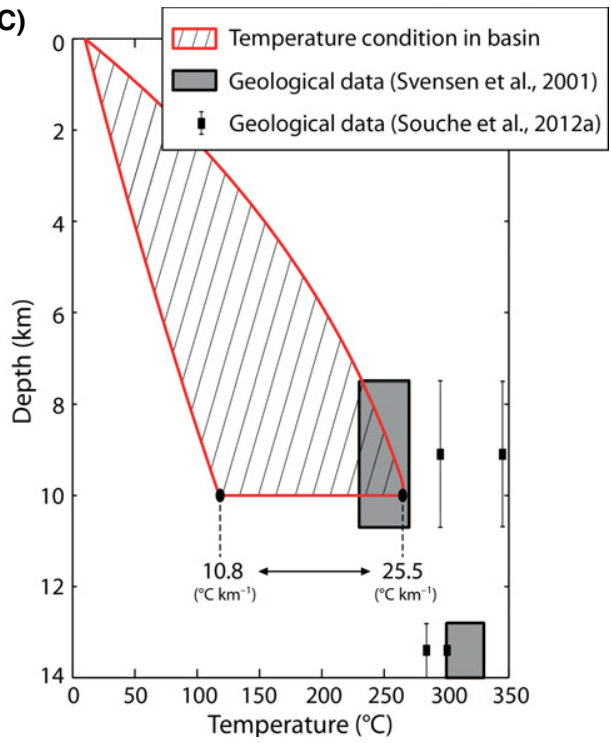

Fig. 9. Thermal evolution (A, B) of the Nordfjord-Sogn Detachment Zone (NSDZ). HP units (black star) initially set to $60 \mathrm{~km}$ and $586^{\circ} \mathrm{C}$ and exhumed to $20 \mathrm{~km}$ depth after $5 \mathrm{Myr}$. [A wet quartzite rheology and a constant shear strain kinematic model are assumed for this simulation; see Souche et al. (2012b)]. The final configuration (B) is the input temperature to the fluid flow simulations performed in this study. (C) Depth-temperature range within the basin at the end of the final configuration (5 Myr) compared with geological data from the Devonian basins of western Norway (Svensen et al. 2001; Souche et al. 2012a).

\section{Mathematical model for thermal convection}

A considerable amount of analytical and numerical experiments have been conducted on the onset of thermal convection using the steady-state form of the Darcy-ObernerckBoussinesq equation where the compressibility is neglected from the mass balance equation and the density variations are linearly dependent on temperature (Lapwood 1948; Wooding 1957; Elder 1967; Combarnous \& Bia 1971; Palm et al. 1972; Bories \& Combarnous 1973; Gupta \& Joseph 1973; Straus 1974; McKibbin \& O'Sullivan 1981; Trew \& McKibbin 1994; Rees \& Postelnicu 2001; Nield \& Bejan 2006). The assumption of neglecting the compressibility in the balance equation, often referred as the Boussinesq approximation, holds for systems characterized by Rayleigh number below 260 (Combarnous \& Bia 1971).

The heat transfer is described by the energy conservation in the fluid and solid phase of the porous medium, assuming thermal equilibrium between them (Eq. 5). For the fluid flow, we assume a quasi-incompressible Darcy flow, meaning that the pore fluid pressure, together with temperature, is taken into account to estimate the density (Fig. 7), the viscosity, and the specific heat of the fluid in Eqs 5 and 6 . However, the Boussinesq approximation is kept such as the density variation is neglected in the mass balance equation of the fluid (Eq. 7a). We further neglect the porosity evolution with time as we are interested in modeling fluid flow in an already formed and compacted basin. Equation 7 a simplifies then to the simple elliptic form of Eq. $7 \mathrm{~b}$.

$$
\left[\phi \rho_{f} C_{P}^{f}+(1-\phi) \rho_{s} C_{P}^{s}\right] \frac{\partial T}{\partial t}+\rho_{f} C_{P}^{f} \mathcal{v} \cdot \nabla T=\nabla \cdot\left(\kappa_{s} \nabla T\right)
$$

$v=\frac{-\kappa}{\mu}\left(\nabla P+\rho_{f} \mathbf{g}\right)$

$$
\frac{\partial\left(\phi \rho_{f}\right)}{\partial t}=-\nabla \cdot\left(\rho_{f} \mathbf{v}\right)
$$

$\nabla \cdot v=0$

where $C_{P}^{f}$ and $C_{P}^{s}$ are the specific heat capacities for fluid and solid, respectively, $T$ is the temperature, and $\kappa_{s}$ is the effective thermal conductivity of the solid, $\phi$ is the porosity, $\rho_{f}$ is the fluid density, $v$ is the seepage velocity, $t$ is time, $\kappa$ is the permeability, $\mu$ is the dynamic fluid viscosity, $P$ is the pore fluid pressure, and $g$ is the gravity acceleration vector.

\section{Numerical approach}

The system of equations (Eqs 5-7) is discretized in space using the standard Galerkin method and solved using a self-developed finite element MATLAB code. A six-node triangular element is used to interpolate the pressure field (piecewise quadratic polynomial interpolation), and a 
three-node triangular element is used to interpolate the temperature field (piecewise linear interpolation). We use Triangle (Shewchuk 1996, 2002) to generate an unstructured triangular mesh resolving the internal boundaries. The computation and assembly of the system of linear equations is performed in the same manner as in the MILAMIN solver (Dabrowski et al. 2008). The fluid properties such as the density, viscosity, and specific heat capacity are evaluated from the pressure and temperature fields at each time step. The fluid properties and the rock transport properties are evaluated in the integration points of each element. The velocity vectors (linear within elements and discontinuous between elements) are obtained by taking the derivative of the pore fluid pressure as expressed in Eq. 6. Diffusion and advection terms in Eq. 5 are split and solved using the fractional step approach. The diffusion step is solved with an implicit scheme. The advection step is explicitly performed with the method of backward characteristics (4th order Runge-Kutta's scheme) combined with the linear interpolation of temperature. An independent check of the numerical diffusion in the advection step was run for several simulations using an unstructured finite volume method employing the MINMOD limiter (Geiger et al. 2004), and no significant differences between the results obtained with the two advection methods were observed.

\section{RESULTS}

We perform a series of numerical simulations in which we vary model parameters to quantify their impact on thermal state in the basin (see Table 3 ). The simulations are run for $1 \mathrm{Myr}$, all starting with the same initial temperature corresponding to the final temperature obtained in the lithospheric model (Fig. 9B). In addition, a reference simulation is also run with only thermal diffusion (no fluid flow) to estimate the temperature anomaly induced by fluid flow.

\section{Model A: Uniform basin-fill}

We assume a uniformly filled sedimentary basin in the configuration I (Fig. 6C), with effective porosity corresponding to an arithmetic weighted average $\left(\phi_{\text {ari }}\right)$ between the

Table 3 Parameters varied in simulation series.

\begin{tabular}{lllll}
\hline & $\begin{array}{l}\text { Basin } \\
\text { configuration }\end{array}$ & Varying parameter & $\begin{array}{l}\text { Min. } \\
\text { value }\end{array}$ & $\begin{array}{l}\text { Max. } \\
\text { value }\end{array}$ \\
\hline Model A I & $\begin{array}{l}\text { Porosity and permeability } \\
\text { of the basin-fill } \\
\text { Thickness of internal } \\
\text { layers }\end{array}$ & $\phi_{B}, \kappa_{B}$ & $\phi_{A}, \kappa_{A}$ \\
Model B II & Pedmeability of the & $200 \mathrm{~m}$ \\
\hline
\end{tabular}

two end-member values characteristic for silt- and sandstone (Eq. 8). The use of the Kozeny-Carman relationship to calculate permeability from the effective porosity would require an additional averaging of the parameters presented in Table 2. Instead, we calculate the effective permeability directly from the permeability of silt- and sandstones, using either arithmetic $\left(\kappa_{\text {ari }}\right)$ or geometric $\left(\kappa_{\text {geo }}\right)$ weighted average (Eqs 9 and 10).

$$
\begin{aligned}
& \phi_{\text {ari }}=X_{1} \cdot \phi_{A}+\left(1-X_{1}\right) \cdot \phi_{B} \\
& \kappa_{\text {ari }}=X_{1} \cdot \kappa_{A}+\left(1-X_{1}\right) \cdot \kappa_{B} \\
& \kappa_{\text {geo }}=\kappa_{A}^{X_{1}} \cdot \kappa_{B}^{1-X_{1}}
\end{aligned}
$$

where $X_{1}$ is the weight coefficient from 0 to 1 .

In the case of $X_{1}=0$ (siltstone basin-fill), no fluid flow occurs in the basin (Fig. 10A) and the heat transfer is diffusive. In the case of $X_{1}=1$ (sandstone basin-fill), significant fluid motion develops in the basin with a maximum seepage magnitude of about $8 \mathrm{~m}$ per year (Fig. 10A), resulting in temperature anomaly in the range between $-82^{\circ} \mathrm{C}$ and $+65^{\circ} \mathrm{C}$. The maximum seepage magnitude is approximately a linear function of $X_{1}$ for arithmetically averaged properties, whereas fluid motion become only significant for $X_{1}>0.6$ in the case of geometric averages.

Figure 10C shows the time when the maxima of the seepage magnitude and the temperature anomaly are attained (using $\phi_{\text {ari }}$ and $\kappa_{\text {ari }}$ ). The maxima of the seepage magnitude and the (positive) temperature anomaly are reached synchronously at the early stage of the process (before $50 \mathrm{kyr}$ ). The early stage is characterized by an unsteady flow, during which the convection cells emerge and organize into a regular pattern. Therefore, the maxima obtained at the early stage of the model could be considered as artifacts related to the unrealistic abrupt transition from the initial conductive background temperature. The minimum (negative) temperature anomaly is reached in a quasi-steady convection regime between 50 and $200 \mathrm{kyr}$ (Fig. 10C) and is therefore less influenced by the initial transition stage than the previous two maxima. The characteristic time required for the development of a quasi-steady convection pattern $(<200 \mathrm{kyr})$ shows that thermal convection operates on a different timescale than thermal diffusion within the lithosphere. Once the stable convection pattern is established, the fluid flow weakens leading to a decrease in the temperature anomaly in the basin (note that the exhumation of the basement is not active in the basin model). As an example, in the simulation where $X_{1}=1$, the cooling in the basin reaches $-82^{\circ} \mathrm{C}$ before approximately $100 \mathrm{kyr}$ and decreases to $-55^{\circ} \mathrm{C}$ at $1 \mathrm{Myr}$ (Fig. 11A). 
(A)

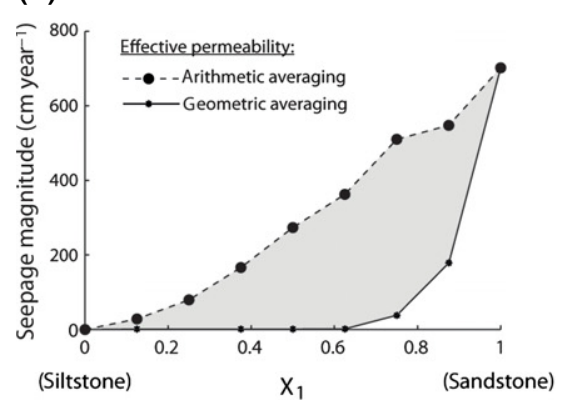

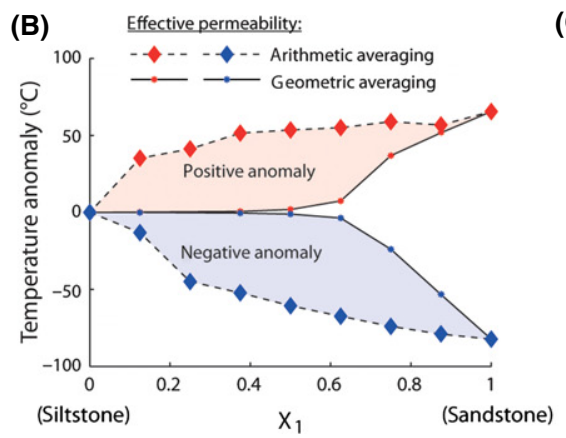

(C)

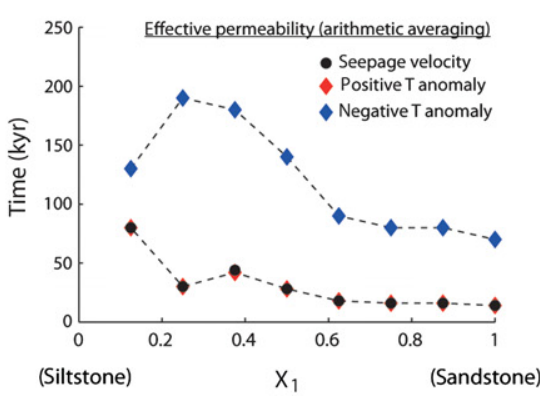

Fig. 10. The maximum of the seepage magnitude $(A)$ and the temperature anomaly extrema (B) as a function of the scaling coefficient $X_{1}$ in the model $A$. (C) Time corresponding to the maxima of the seepage magnitude and the temperature anomaly.

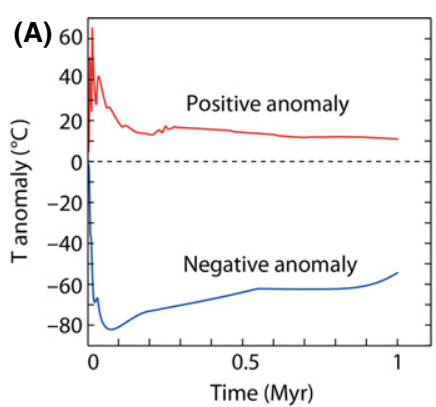

(F) Max. seepage velocity $\left(\mathrm{cm} \mathrm{ear}^{-1}\right)$

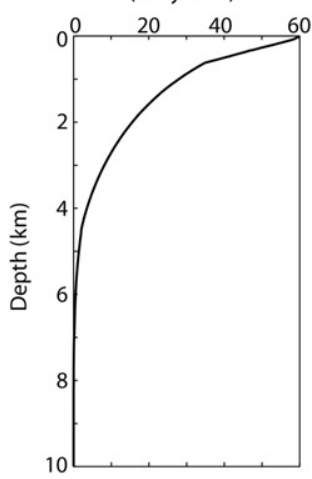

(G) Temperature in basin

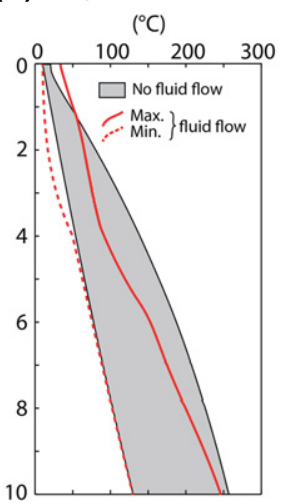

(B)
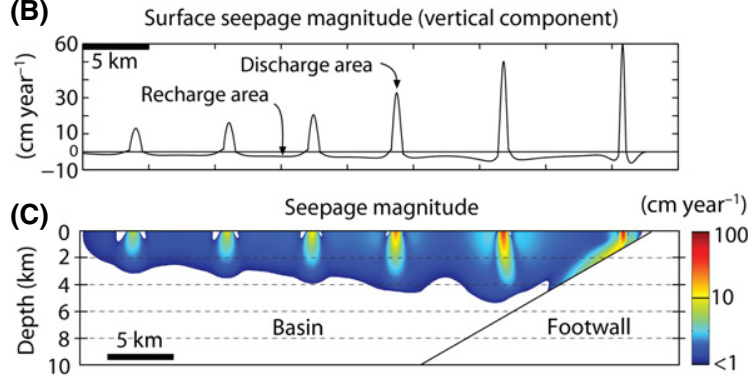

(D)
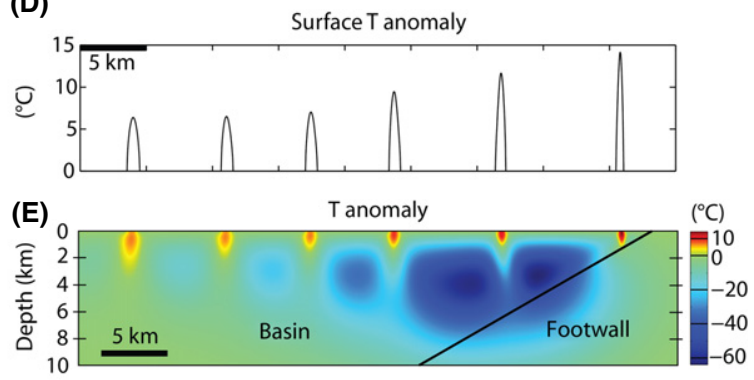

Fig. 11. Results of the model $A$ for $X_{1}=1$ (sandstone basin-fill). (A) Temperature anomaly evolution over a period of 1 Myr. The results presented in (B-G) are taken at $500 \mathrm{kyr}$. (B) Vertical component of the seepage velocity at the surface. (C) Seepage magnitude in the basin. (D) Surface and (E) basin temperature anomaly induced by fluid flow. (F) Maximum seepage magnitude as a function of depth. (G) Maximum and minimum temperatures in the basin as a function of depth for conductive model and fluid flow model.

Figure 11 shows the results for $X_{1}=1$, which is the most favorable fluid flow scenario. At quasi-steady-state, the convection cells organize into a regular pattern characterized by narrow upwellings evenly spaced between 5 and $8 \mathrm{~km}$ (Fig. 11C,E). At the surface, the recharge is characterized by a downward flow in the order of few $\mathrm{cm}$ per year and takes place over large areas (Fig. 11B). In comparison, the discharge areas are characterized by a narrow upward flow with velocities in the order of several dozens of $\mathrm{cm}$ per year resulting in local 'hot springs' at the surface (Fig. 11D). The infiltration of fluids reaches deeper parts of the basin close to the detachment fault where the temperature gradient is high. The fluid circulation affects significantly the thermal structure of the basin and results in a maximum cooling at about 3-6 km depth (Fig. 11E,G). Note that the most prominent thermal anomaly (cooling) coincides with large drainage areas associated with relatively slow downward fluid flow (Fig. 11F,G). 

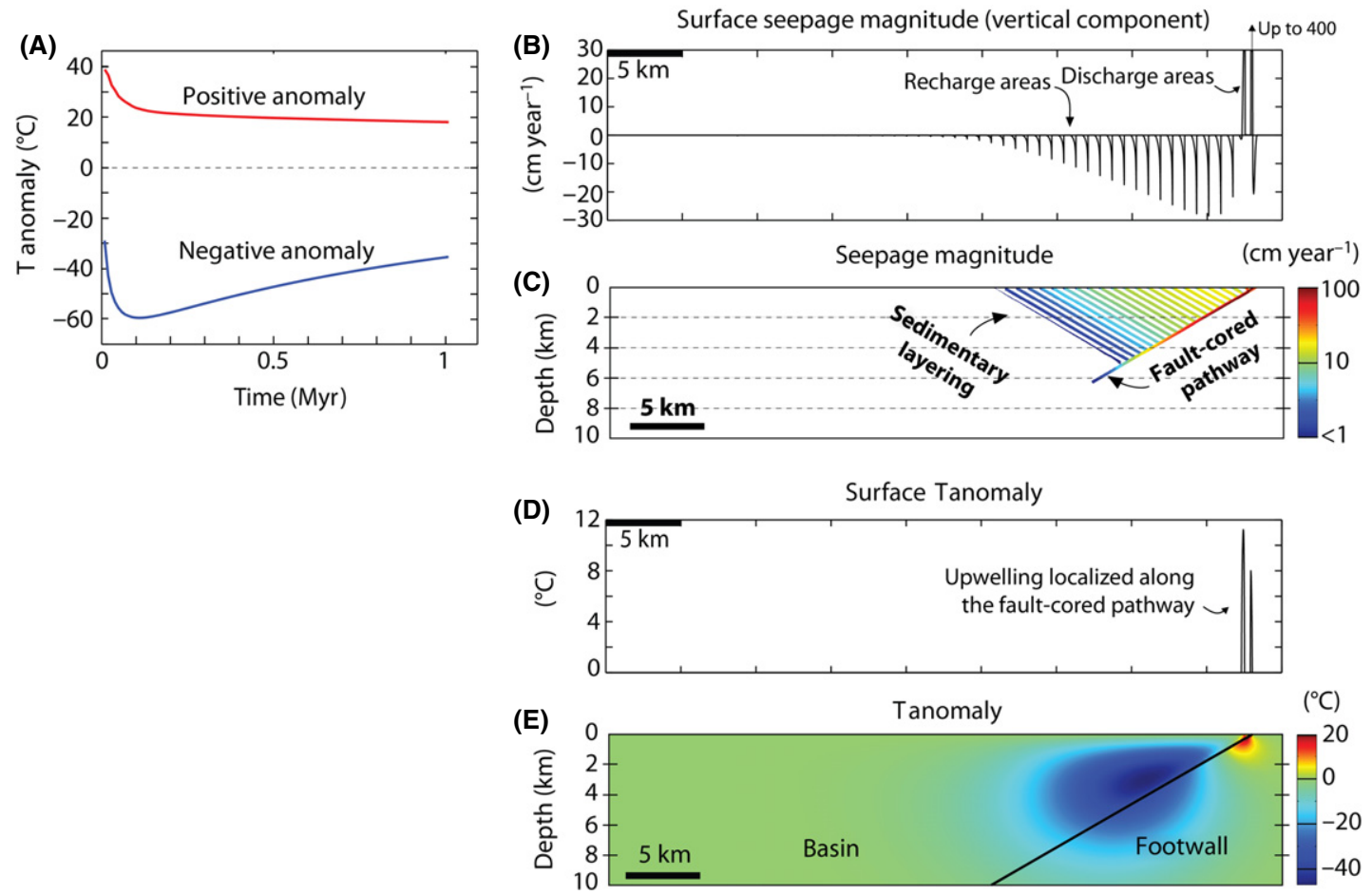

Fig. 12. Results of the model $B$ with the internal layer thickness set to $200 \mathrm{~m}$. (A) Temperature anomaly evolution over a period of $1 \mathrm{Ma}$. The results presented in (B-E) are taken at $500 \mathrm{kyr}$. (B) Vertical component of the seepage velocity at the surface. (C) Seepage magnitude in the basin. (D) Surface and (E) basin temperature anomaly induced by fluid flow.

\section{Model B: Basin layering}

In the model B, we use the basin configuration II (Fig. 6D) with a stack of alternating sandstone and siltstone layers with thicknesses varying from 50 to $200 \mathrm{~m}$. A fault-cored fluid pathway is present along the detachment with a porosity of $\phi_{A}$, a permeability of $10 \cdot \kappa_{A}$, and a thickness of $200 \mathrm{~m}$. In contrast with the model A, where the early stage is characterized by unsteady fluid flow, the fluid circulation pattern in the model B is immediately set by the presence of the layers. The fluid flow takes place within the permeable network formed by the sandstone layers and the fault-cored pathway. The presence of the fault-cored pathway is critical as it allows the fluids to channelize upward along the detachment. Fluid motion would be inhibited without the presence of the faultcored pathway. The minimum (negative) temperature anomaly reaches $-60^{\circ} \mathrm{C}$ in the basin at approximately $100 \mathrm{kyr}$ (Fig. 12A) and is independent of the thickness of the internal layers. Figure 12 shows the results for internal layer thickness set to $200 \mathrm{~m}$. The results obtained for internal layer thickness set to 50,100 , and $150 \mathrm{~m}$ are not significantly different.

The fluid flow pattern is characterized by a dominant downward flow along the sandstone layers with seepage magnitude of about $10-30 \mathrm{~cm}$ per year and a localized upward flow along the fault-cored pathway with seepage velocity up to $4 \mathrm{~m}$ per year (Fig. 12B). The fluid flow results in cooling almost everywhere in the basin and local heating in the vicinity of the detachment (Fig. 12E). Similarly to the model $\mathrm{A}$, the most significant cooling of the basin occurs at depth of $3-5 \mathrm{~km}$ as a result of basin-scale drainage associated with relatively slow downward fluid flow along the permeable sandstone layers.

\section{Model C: Permeability of the fault-cored pathway}

Several numerical studies have investigated fluid circulation along fault zone using effective permeabilities in the range of $1-100 \mathrm{mD}$ to a depth of several kilometers (Garven et al. 2001; Simms \& Garven 2004; Yang et al. 2004; Shalev et al. 2007; Fairley 2009; Harcouët-Menou et al. 2009; Magri et al. 2012). In our model, the fault-cored pathway represents the fanglomerates and the fractured rocks along the tectonic contact between the basin and the detachment. In this set of numerical experiments, we systematically vary the permeability of the fault-cored pathway by rescaling the permeability used for sandstones (Fig. 8B) with a coefficient $X_{3}$ (Eq. 12) set from 1 to 30. Thus, for $X_{3}=1$, the surface permeability of the fault-cored pathway is $395 \mathrm{mD}$ and decreases to $1,2 \mathrm{mD}$ at $5 \mathrm{~km}$ depth. We consider a siltstone basin-fill, which inhibits the fluid flow in the basin. The thickness of the fault-cored pathway is set to $200 \mathrm{~m}$, and the transport properties are set to 
$\phi_{\text {path }}=\phi_{A}$

$$
\kappa_{\text {path }}=X_{3} \cdot \kappa_{A}
$$

The seepage magnitude increases with increasing value of $X_{3}$ (Fig. 13A). Abrupt changes in seepage magnitude occur at approximately $X_{3}=10$ and $X_{3}=25$ and reflect the reconfiguration of convection cells within the faultcored pathway (Fig. 13C-E). The results obtained for $1>X_{3}>10$ show unicellular convection cells that are typical for non-Rayleigh convection (Fig. 13C) with upward flow along the warmer wall of the pathway and downward flow along the colder wall. For $X_{3}>10$, the flow pattern is characterized by multicellular convection that is typical for Rayleigh convection. For $10>X_{3}>25$, the flow pattern organize into regularly spaced convection cells in the upper $3 \mathrm{~km}$ of the fault-cored pathway (Fig. 13D). For $X_{3}$ above 25 , the convection pattern is irregular with the presence of a large convection cell in the upper $2 \mathrm{~km}$ of the fault-cored pathway with a distinct downward flow along the warmer wall of the detachment and upward flow along the colder wall.

The temperature anomalies due to non-Rayleigh convection are on the order of $\pm 1^{\circ} \mathrm{C}$. In the Rayleigh convection mode, the temperature anomalies do not exceed $+10 /$ $-15^{\circ} \mathrm{C}$ even for maximum seepage velocities of approximately $5 \mathrm{~m}$ per year (Fig. 13A). The confinement of the fluid flow within the narrow pathway seems to strongly limit the heat transfer caused by convection in the system.

\section{SUMMARY AND DISCUSSION}

Figure 14 shows the range of minimum (negative) temperature anomalies caused by fluid flow in the models A, B, and $\mathrm{C}$. The results obtained with the models $\mathrm{A}$ and $\mathrm{B}$ show a significant regional cooling up to $82^{\circ} \mathrm{C}$ in the case of a uniform sandstone basin-fill. The restricted fluid circulation within the fault-cored pathway (model C) precludes significant heat redistribution in the system even with high seepage velocities of several meters per year, which are similar in magnitude to those of the models A and B.

\section{Effective transport properties}

The minimum (negative) temperature anomaly in the model A obtained with an arithmetic averaging of the transport properties with an equal fraction of sandstone and siltstone $\left(X_{1}=0.5\right)$ and in the model $\mathrm{B}$ with alternating layers

(A)

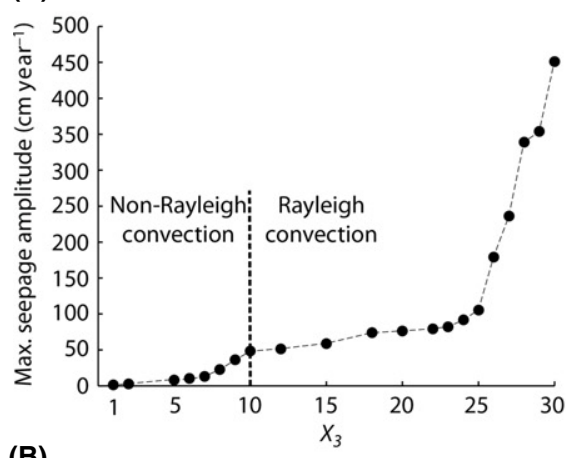

(B)
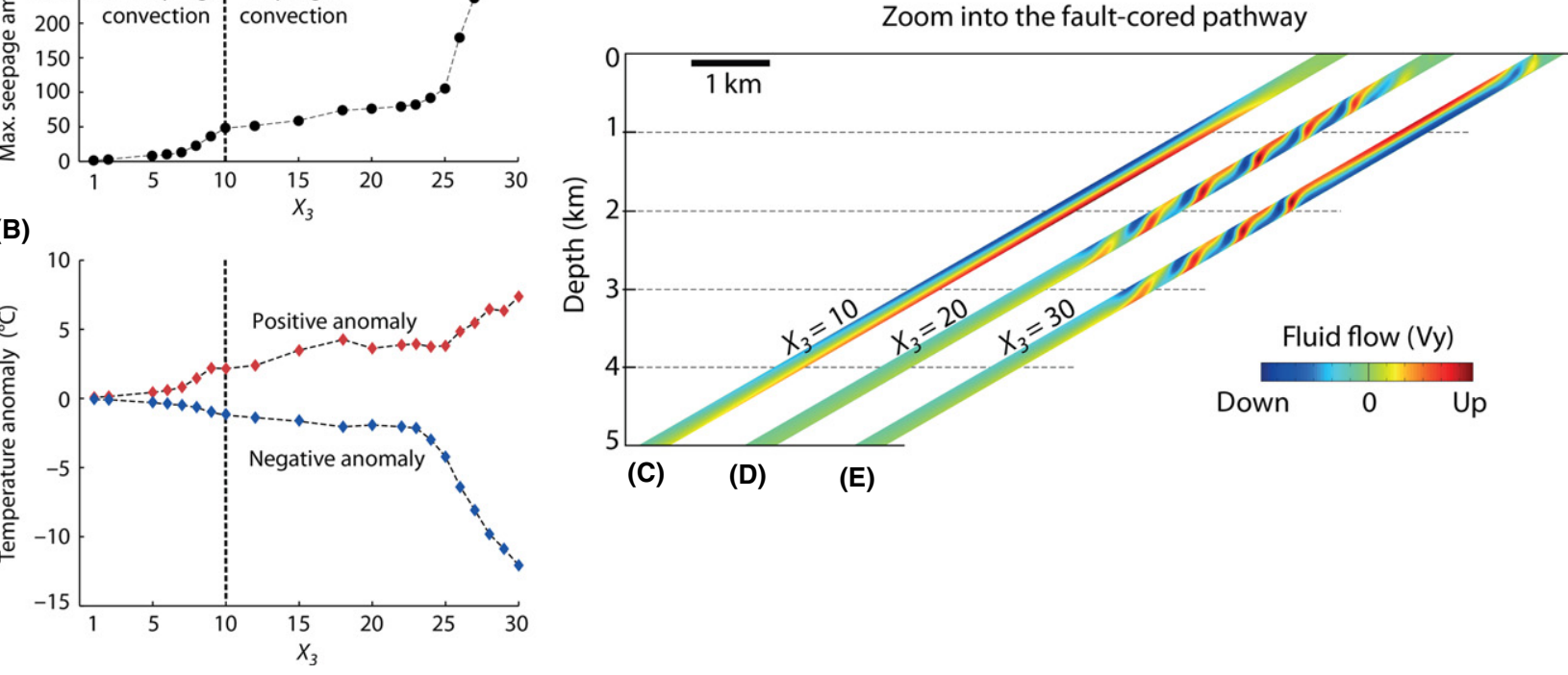

(C) (D) (E)

Fig. 13. Results of the model $\mathrm{C}$ with the fault-cored pathway thickness set to $200 \mathrm{~m}$. (A) Maximum of the seepage magnitude. (B) Temperature anomaly extrema as a function of $X_{3}$. (C-E) Vertical component of the seepage velocity (arbitrary color-scale) in the fault-cored pathway at 500 kyr (quasi-steadystate pattern) obtained for $X_{3}=10, X_{3}=20$ and $X_{3}=30$. The upper $5 \mathrm{~km}$ of the fault-cored pathway is shown. (C) Non-Rayleigh convection (unicellular convection). (D) Rayleigh convection with regular spacing between the convection cells. (C) Rayleigh convection with irregular spacing between the convection cells. 


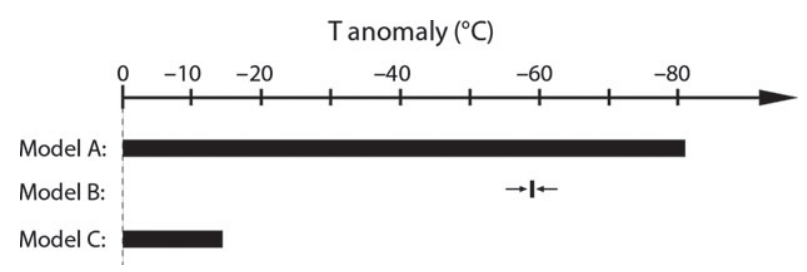

Fig. 14. Range of minimum (negative) temperature anomalies in the models $\mathrm{A}, \mathrm{B}$, and $\mathrm{C}$.

of sandstone and siltstone are, respectively, 62 and $59^{\circ} \mathrm{C}$. The arithmetic average of silt- and sandstone permeability used in the model A corresponds to the transport property parallel to the bedding of a stratified medium (Dagan 1989) such as the one present in the model B. However, the component of the effective permeability describing transport normal to the stratification is given by the harmonic average, which may be significantly lower than the arithmetic average. Irrespective of this discrepancy between the transport properties in the models $\mathrm{A}$ and $\mathrm{B}$, the temperature anomaly is almost the same. We speculate that the presence of the fault-cored pathway in the model B (permeability $10 \kappa_{A}$ ) may compensate for a low transport property normal to the layer stack in the basin. Note that the value of the effective permeability obtained with geometric averaging corresponds to a random distribution of silt- and sandstone and lies between the parallel and the normal flow obtained in a stratified medium (Dagan 1989).

\section{Effect of the sedimentary layering}

The occurrence of a significant fluid flow and thermal feedback in the case of a layered basin-fill with almost impermeable siltstone layers contrasts with previous suggestions that thermal convection in sedimentary basin is inhibited by the presence of meter-thick impermeable layers (Bjørlykke et al. 1988). However, we emphasize that, in our simulations, there is an interconnecting highly permeable pathway at the base of the basin and that thermally driven flow occurs as a transient process caused by slanted isotherms during the exhumation of a crustal-scale detachment footwall. Once the thermal perturbation associated with exhumation processes is relaxed, the thermal convection in the basin ceases under the regional thermal gradient.

\section{Temperature conditions of the Devonian basins}

In the models $\mathrm{A}$ and $\mathrm{B}$, the fluid flow affects the thermal structure of the basin mainly at $3-6 \mathrm{~km}$ depth. The fluid flow is inhibited by the reduced porosity and permeability below this range, and thermal convection does not operate efficiently. In the context of the Devonian basins of western Norway, which have an estimated burial depth of about $10 \mathrm{~km}$ (Svensen et al. 2001), thermally driven flow may have not influence the peak temperature conditions of the sediments. The alteration of ultramafic clasts of the conglomerates in the Solund basin (Beinlich et al. 2010) and the pervasive oxidation the Devonian basins of western Norway may partially result from basin-scale fluid flow during the burial of the sediments. However, the temperature evolution during the formation of the basin cannot be directly addressed in our models and would require the consideration of additional effects in the fluid flow budget such as the compaction of the basin.

\section{Fluid flow in the detachment pathway}

The flow and heat transport in the model $\mathrm{C}$ is similar to thermal convection in isolated tilted layers (Bories \& Combarnous 1973; McKibbin \& O'Sullivan 1981; Wood \& Hewett 1982). The onset of Rayleigh convection can be expected above a critical value of the Rayleigh number that, in geological systems, varies mostly due to changes in the permeability, thickness, and temperature gradient across the layer. In our model, the temperature gradient is determined by the initial background temperature. The onset of Rayleigh convection occurs for a pathway permeability of $10 \kappa_{A}$ and a layer thickness of $200 \mathrm{~m}$. As permeability contributes in the same proportion as the square of the thickness to the Rayleigh number, an equivalent Rayleigh number would be found setting the permeability to $\kappa_{A}$ and the layer thickness to approximately $630 \mathrm{~m}$ (assuming that the thermal gradient would not change across the layer). Such thick detachment pathway might be large considering the geological framework, but would lead to more significant thermal anomalies in the system due to a larger drainage area.

The model C suggests that high fluid velocities inside the detachment shear zone might not necessarily induce large cooling of the system if the flow is constrained within a narrow pathway. The regional cooling occurs only if the fluid flow infiltrates from extended areas in the hanging wall, as illustrated by the models A and B. These results agree well with similar conclusions drawn by Ferguson et al. (2009) regarding significant depression of isotherms in the hanging walls of crustal-scale faults due to groundwater flow.

These results can help to understand heat transfer induced by fluid flow in detachment zones where high thermal gradients of $140^{\circ} \mathrm{C} / 100 \mathrm{~m}$ are documented (Mulch et al. 2006; Gottardi et al. 2011). Our results show that the cooling of the metamorphic rocks in the basement can be significant if the fluid flow in the detachment zone drains the supradetachment basin.

\section{Pore fluid composition}

The consequences of diagenetic processes are ignored in our model. The model parameters such as the density, the 
viscosity, and the heat capacity of water depend on the concentration of solutes that dissolve from the surrounding sedimentary matrix. The studied geological system is dominated by continental siliciclastic sediments highly cemented by carbonate minerals. The change of density with depth in sedimentary basin is positive for silicates in solution and negative for carbonates and these two contributions nearly cancel out in sandstone formations with carbonate cement (Bjørlykke et al. 1988). The most significant density variation of the pore fluid with depth could come from soluble salts in the basin potentially inhibiting thermal convection by introducing a negative density gradient with depth. However, salt deposits are not found in our geological setting. The fluid-inclusion analysis from metamorphic veins in the deepest part of the Devonian basins of western Norway (Svensen et al. 2001) documents salinity close to modern seawater. However, the metamorphic veins formed in the deepest part of the basin at about $10 \mathrm{~km}$ when the sediments were compacted and the origin of the salinity could come from metamorphic processes (Svensen et al. 2001). From our modeling, we know that the circulation of meteoritic water did not reach such depth and we assume that the metamorphic fluid found in the veins may have been decoupled from the meteoritic water circulation in shallower part of the basin. Thus, using pure water as a pore fluid in our models is a feasible approximation.

\section{D approach and generalization to 3D}

We use the $2 \mathrm{D}$ approach to study the flow pattern in the basin. Different flow configurations can develop in 3D models of porous convection. The question arises as to whether such effects would significantly influence the heat transfer efficiency in the basin. Based on a simplified 3D model of crustal-scale detachment, Harcouët-Menou et al. (2009) studied the flow pattern of thermal convection in sedimentary basin bounded by a highly permeable shear zone conduit. Their results show the development of polyhedral convection cells (3D structures) within the shear zone and the transition to convection coils (quasi-2D structures) in the basin parallel to the shear zone direction. Garven et al. (2001) investigated the underground temperature distribution along the hydrothermal system of the Borax Lake fault in the USA. From their study, the warmer temperatures at depth correspond to circular thermal anomalies within the fault system and suggest an upwelling of hot fluids in a chimney-like conduit. These papers clearly illustrate the complexity that we can expect in the case of convective flow patterns in natural systems. However, the scaling between the Nusselt (dimensionless number describing the heat transfer efficiency) and Rayleigh number should remain similar in the case of 2D and 3D models for low Rayleigh number values (Combarnous \& Bia 1971). Therefore, our 2D model should provide a reliable estimate of the heat transfer budget for sedimentary basins, which are characterized by low values of the Rayleigh number.

\section{CONCLUSIONS}

We have studied the thermal anomaly induced by thermal convection in supradetachment basins above an active crustal-scale detachment zone. The interplay between fluid flow and heat transfer has been modeled with and without the presence of sedimentary layers and fluid pathways along the detachment. Our conclusions are as follows:

(1) Thermal convection can develop as transient process above crustal-scale detachments and result in a significant thermal effect in the supradetachment basins.

(2) From the specific study of the Devonian basins of western Norway, our numerical model shows that the fluid circulation may have reached a depth of about $5 \mathrm{~km}$ and resulted in the cooling of the basin up to approximately $80^{\circ} \mathrm{C}$.

(3) The presence of barrier-like siltstone layers does not inhibit the flow as long as there is interconnectivity of the permeable layers in the basin. The fluid pathway along the detachment may play an important role in draining meteoritic fluid through the basin.

(4) The fluid pathway along the detachment can host a high velocity fluid flow but cannot induce large temperature anomaly below and above the detachment if there is no flow from the basin or the hanging wall.

(5) The Devonian basins of western Norway reached a burial depth where thermal convection is no longer expected to contribute to the heat transfer. Thus, the peak temperature estimates for these basins may be interpreted with conductive heat transfer. However, the alteration of the sediments may partially results from large-scale fluid flow during the burial of the basins.

\section{ACKNOWLEDGEMENTS}

The Norwegian Science Council provided basic funding although a 'Centre of Excellence' grant to Physics of Geological Processes (PGP). The Norwegian Academy of Science and Letters and Statoil are thanked for the financial support through the VISTA grant 6255. The authors would like to thank $\mathrm{K}$. Iyer and L. Rüpke for providing the fluid property tables used in this study. Thanks to $S$. Medvedev for discussions and advice during the elaboration of the manuscript.

\section{REFERENCES}

Andersen TB (1998) Extensional tectonics in the Caledonides of southern Norway, an overview. Tectonophysics, 285, 333-51.

Andersen TB, Jamtveit B (1990) Uplift of deep crust during orogenic extensional collapse: a model based on field studies in 
the Sogn-Sunnfjord Region of western Norway. Tectonics, 9, 1097-111.

Andrews JN, Burgess WG, Edmunds WM, Kay RLF, Lee DJ (1982) The thermal springs of bath. Nature, 298, 339-43.

Athy LF (1930) Density, porosity, and compaction of sedimentary rocks. American Association of Petroleum Geologists Bulletin, 14, $1-24$.

Bauer O (1998) PROperties of Water and STeam, PROST 4.1. Technische Universitat Hamburg-Harburg, Hamburg.

Beinlich A, Austrheim H, Glodny J, Erambert M, Andersen TB (2010) $\mathrm{CO}_{2}$ sequestration and extreme $\mathrm{Mg}$ depletion in serpentinized peridotite clasts from the Devonian Solund basin, SW-Norway. Geochimica et Cosmochimica Acta, 74, 6935-64.

Bjørlykke K (1999) Principal aspects of compaction and fluid flow in mudstones. Geological Society, London, Special Publications, 158, 73-8.

Bjørlykke K, Høeg K (1997) Effects of burial diagenesis on stresses, compaction and fluid flow in sedimentary basins. Marine and Petroleum Geology, 14, 267-76.

Bjørlykke K, Mo A, Palm E (1988) Modelling of thermal convection in sedimentary basins and its relevance to diagenetic reactions. Marine and Petroleum Geology, 5, 338-51.

Bories SA, Combarnous MA (1973) Natural convection in a sloping porous layer. Journal of Fluid Mechanics, 57, 63-79.

Braathen A, Osmundsen PT, Gabrielsen RH (2004) Dynamic development of fault rocks in a crustal-scale detachment: an example from western Norway. Tectonics, 23, TC4010.

Brumm M, Wang CY, Manga M (2009) Spring temperatures in the Sagehen Basin, Sierra Nevada, CA: implications for heat flow and groundwater circulation. Geofluids, 9, 195-207.

Bryhni I (1964) Migrating basins on the old red continent. Nature, 202, 384-5.

Clauser C, Huenges E (1995) Thermal conductivity of rocks and minerals. In: Rock Physics \& Phase Relations: A Handbook of Physical Constants (ed. Ahrens TJ), Vol. 3, pp. 105-26. AGU, Washington, D.C.

Combarnous MA, Bia P (1971) Combined free and forced convection in porous media. Society of Petroleum Engineers, 11, 399-405.

Dabrowski M, Krotkiewski M, Schmid DW (2008) MILAMIN: MATLAB-based finite element method solver for large problems. Geochemistry, Geophysics, Geosystems, 9, Q04030.

Dagan G (1989) Flow and Transport in Porous Formations. Springer, Berlin.

Elder JW (1967) Steady free convection in a porous medium heated from below. Journal of Fluid Mechanics, 27, 29-48.

Fairley JP (2009) Modeling fluid flow in a heterogeneous, faultcontrolled hydrothermal system. Geofluids, 9, 153-66.

Ferguson G, Grasby SE, Hindle SR (2009) What do aqueous geothermometers really tell us? Geofluids, 9, 39-48.

Folkestad A, Steel RJ (2001) The alluvial cyclicity in Hornelen basin (Devonian Western Norway) revisited: a multiparameter sedimentary analysis and stratigraphic implications. In: Norwegian Petroleum Society Special Publications (eds Ole JM, Tom D), Vol. 10, pp. 39-50. Elsevier, Amsterdam.

Garven G, Bull SW, Large RR (2001) Hydrothermal fluid flow models of stratiform ore genesis in the McArthur Basin, Northern Territory, Australia. Geofluids, 1, 289-311.

Geiger S, Roberts S, Matthäi SK, Zoppou C, Burri A (2004) Combining finite element and finite volume methods for efficient multiphase flow simulations in highly heterogeneous and structurally complex geologic media. Geofluids, 4, 28499.
Gottardi R, Teyssier C, Mulch A, Vennemann TW, Wells ML (2011) Preservation of an extreme transient geotherm in the Raft River detachment shear zone. Geology, 39, 759-62.

Gouze P, Coudrain-Ribstein A, Bernard D (1994) Computation of porosity redistribution resulting from thermal convection in slanted porous layers. Journal of Geophysical Research, 99, 697706.

Gupta VP, Joseph DD (1973) Bounds for heat transport in a porous layer. Journal of Fluid Mechanics, 57, 491-514.

Hacker BR, Andersen TB, Root DB, Mehl L, Mattinson JM, Wooden JL (2003) Exhumation of high-pressure rocks beneath the Solund Basin, Western Gneiss Region of Norway. Journal of Metamorphic Geology, 21, 613-29.

Hacker BR, Andersen TB, Johnston S, Kylander-Clark ARC, Peterman EM, Walsh EO, Young D (2010) High-temperature deformation during continental-margin subduction \& exhumation: the ultrahigh-pressure Western Gneiss Region of Norway. Tectonophysics, 480, 149-71.

Hantschel T, Kauerauf AI (2009) Fundamentals of Basin and Petroleum Systems Modeling. Springer-Verlag, Berlin, Heidelberg.

Harcouët-Menou V, Guillou-Frottier L, Bonneville A, Adler PM, Mourzenko V (2009) Hydrothermal convection in and around mineralized fault zones: insights from two- and threedimensional numerical modeling applied to the Ashanti belt, Ghana. Geofluids, 9, 116-37.

Hasterok D, Chapman DS (2011) Heat production and geotherms for the continental lithosphere. Earth and Planetary Science Letters, 307, 59-70.

Hidalgo JJ, Carrera J (2009) Effect of dispersion on the onset of convection during $\mathrm{CO}_{2}$ sequestration. Journal of Fluid Mechanics, 640, 441-52.

Ingebritsen SE, Manning CE (1999) Geological implications of a permeability-depth curve for the continental crust. Geology, 27, 1107-10.

Johnston S, Hacker BR, Ducea MN (2007) Exhumation of ultrahigh-pressure rocks beneath the Hornelen segment of the Nordfjord-Sogn Detachment Zone, western Norway. Geological Society of America Bulletin, 119, 1232-48.

Krabbendam M, Dewey JF (1998) Exhumation of UHP rocks by transtension in the Western Gneiss Region, Scandinavian Caledonides. Geological Society, London, Special Publications, $135,159-81$.

Kylander-Clark ARC, Hacker BR, Johnson CM, Beard BL, Mahlen NJ (2009) Slow subduction of a thick ultrahighpressure terrane. Tectonics, 28, TC2003.

Labrousse L, Jolivet L, Andersen TB, Agard P, Hébert R, Maluski H, Schärer U (2004) Pressure-temperature-time deformation history of the exhumation of ultra-high pressure rocks in the Western Gneiss Region, Norway. Geological Society of America Special Papers, 380, 155-83.

Lapwood ER (1948) Convection of a fluid in a porous medium. Mathematical Proceedings of the Cambridge Philosophical Society, 44, 508-21.

Levet S, Toutain JP, Munoz M, Berger G, Negrel P, Jendrzejewski N, Agrinier P, Sortino F (2002) Geochemistry of the Bagnères-de-Bigorre thermal waters from the North Pyrenean Zone (France). Geofluids, 2, 25-40.

Magri F, Akar T, Gemici U, Pekdeger A (2012) Numerical investigations of fault-induced seawater circulation in the Seferihisar-Balçova Geothermal system, western Turkey. Hydrogeology Journal, 20, 103-18.

Manning CE, Ingebritsen SE (1999) Permeability of the continental crust: implications of geothermal data and metamorphic systems. Reviews of Geophysics, 37, 127-50. 
Marques FO, Schmid DW, Andersen TB (2007) Applications of inclusion behaviour models to a major shear zone system: the Nordfjord-Sogn Detachment Zone in western Norway. Journal of Structural Geology, 29, 1622-31.

McKibbin R, O'Sullivan MJ (1981) Heat transfer in a layered porous medium heated from below. Journal of Fluid Mechanics, $111,141-73$.

Mulch A, Teyssier C, Cosca MA, Vennemann TW (2006) Thermomechanical analysis of strain localization in a ductile detachment zone. Journal of Geophysical Research B: Solid Earth, $111, \mathrm{~B} 12405$.

Nield DA, Bejan A (2006) Convection in Porous Media. Springer, New York.

Nilsen TH, McLaughlin RJ (1985) Comparison of tectonic framework and depositional patterns of the Hornelen strike-slip basin of Norway and the Ridge and Little Sulphur Creek strikeslip basins of California. Society of Economic Paleontologists and Mineralogists, Special Publication, 37, 79-103.

Norton MG (1986) Late Caledonide extension in western Norway: a response to extreme crustal thickening. Tectonics, $\mathbf{5}$, 195-204.

Odling NE, Larsen $\varnothing$ (2000) Vein architecture in the Devonian sandstones of the Hornelen basin, western Norway, and implications for the palaeostrain history. Norsk Geologisk Tidsskrift, 80, 289-99.

Osmundsen PT, Andersen TB (2001) The middle Devonian basins of western Norway: sedimentary response to large-scale transtensional tectonics? Tectonophysics, 332, 51-68.

Osmundsen PT, Andersen TB, Markussen S, Svendby AK (1998) Tectonics and sedimentation in the hangingwall of a major extensional detachment: the Devonian Kvamshesten Basin, western Norway. Basin Research, 10, 213-34.

Osmundsen PT, Bakke B, Svendby AK, Andersen TB (2000) Architecture of the middle Devonian Kvamshesten group, Western Norway: sedimentary response to deformation above a ramp-flat extensional fault, 503-35.

Palm E, Weber JE, Kvernvold O (1972) On steady convection in a porous medium. Journal of Fluid Mechanics, 54, 153-61.

Pau GSH, Bell JB, Pruess K, Almgren AS, Lijewski MJ, Zhang K (2010) High-resolution simulation and characterization of density-driven flow in $\mathrm{CO}_{2}$ storage in saline aquifers. Advances in Water Resources, 33, 443-55.

Person M, Raffensperger JP, Ge S, Garven G (1996) Basin-scale hydrogeologic modeling. Reviews of Geophysics, 34, 61-87.

Rees DAS, Postelnicu A (2001) The onset of convection in an inclined anisotropic porous layer. International Journal of Heat and Mass Transfer, 44, 4127-38.

Root DB, Hacker BR, Gans PB, Ducea MN, Eide EA, Mosenfelder JL (2005) Discrete ultrahigh-pressure domains in the Western Gneiss Region, Norway: implications for formation and exhumation. Journal of Metamorphic Geology, 23, 45-61.

Sclater JG, Christie PAF (1980) Continental stretching: an explanation of the post-Mid-Cretaceous subsidence of the Central North Sea Basin. Journal of Geophysical Research, 85, 3711-39.

Seguret M, Seranne M, Chauvet A, Brunel M (1989) Collapse basin: a new type of extensional sedimentary basin from the Devonian of Norway. Geology, 17, 127-30.

Seranne M, Seguret M (1987) The Devonian basins of western Norway: tectonics and kinematics of an extending crust. Journal of the Geological Society, London, Special Publications, 28, $537-48$.
Shalev E, Lyakhovsky V, Yechieli Y (2007) Is advective heat transport significant at the Dead Sea basin? Geofluids, 7, 292300.

Shewchuk J (1996) Triangle: engineering a 2D quality mesh generator and Delaunay triangulator. In: Applied Computational Geometry Towards Geometric Engineering (eds Lin M, Manocha D), Vol. 1148, pp. 203-22. Springer, Berlin - Heidelberg.

Shewchuk JR (2002) Delaunay refinement algorithms for triangular mesh generation. Computational Geometry, 22, 21-74.

Simms MA, Garven G (2004) Thermal convection in faulted extensional sedimentary basins: theoretical results from finiteelement modeling. Geofluids, 4, 109-30.

Souche A, Beyssac O, Andersen TB (2012a) Thermal structure of supra-detachment basins: a case study of the Devonian basins of western Norway. Journal of the Geological Society, London, 10, 213-34.

Souche A, Medvedev S, Andersen TB, Dabrowski M (2012b) Shear heating in extensional detachments: implications for the thermal history of the Devonian basins of western Norway. Part of Alban Souche's PhD thesis, Series of dissertations submitted to the Faculty of Mathematics and Natural Sciences, University of Oslo, No. 1254, ISSN 1501-7710.

Steel RJ, Næhle S, Nilsen H, Røe SL, Spinnangr A (1977) Coarsening-upward cycles in the alluvium of Hornelen Basin (Devonian) Norway: sedimentary response to tectonic events. Geological Society of America Bulletin, 88, 1124-34.

Straus JM (1974) Large amplitude convection in porous media. Journal of Fluid Mechanics, 64, 51-63.

Svensen H, Jamtveit B, Banks DA, Karlsen D (2001) Fluids and halogens at the diagenetic-metamorphic boundary: evidence from veins in continental basins, western Norway. Geofluids, 1, 53-70.

Torsvik TH, Sturt BA, Swensson E, Andersen TB, Dewey JF (1992) Palaeomagnetic dating of fault rocks: evidence for Permian and Mesozoic movements and brittle deformation along the extensional Dalsfjord Fault, western Norway. Geophysical Journal International, 109, 565-80.

Trew M, McKibbin R (1994) Convection in anisotropic inclined porous layers. Transport in Porous Media, 17, 271-83.

Ungerer P, Burrus J, Doligez B, Chenet PY, Bessis F (1990) Basin evaluation by integrated two-dimensional modeling of heat transfer, fluid flow, hydrocarbon generation, and migration. American Association of Petroleum Geologists Bulletin, 74, 30935.

Wangen M (1994) Numerical simulation of thermal convection in compacting sedimentary basins. Geophysical Journal International, 119, 129-50.

Wangen M (1997) Non-Rayleigh convection caused by ground surface topography. Transport in Porous Media, 26, 299-318.

Wood JR, Hewett TA (1982) Fluid convection and mass transfer in porous sandstones - a theoretical model. Geochimica et Cosmochimica Acta, 46, 1707-13.

Wooding RA (1957) Steady state free thermal convection of liquid in a saturated permeable medium. Journal of Fluid Mechanics, 2, 273-85.

Yang J, Large RR, Bull SW (2004) Factors controlling free thermal convection in faults in sedimentary basins: implications for the formation of zinc-lead mineral deposits. Geofluids, 4, 237-47.

Young DJ, Hacker BR, Andersen TB, Gans PB (2011) Structure and $40 \mathrm{Ar} / 39 \mathrm{Ar}$ thermochronology of an ultrahigh-pressure transition in western Norway. Journal of the Geological Society, $168,887-98$. 